\title{
$5-2019$
}

\section{Risk Dynamics Around Restatement Announcements}

\author{
Katsiaryna Salavei Bardos \\ Fairfield University, kbardos@fairfield.edu \\ Brandon N. Kline \\ Gregory Koutmos \\ Fairfield University, GKoutmos@fairfield.edu
}

Follow this and additional works at: https://digitalcommons.fairfield.edu/business-facultypubs Copyright (C) 2019, Springer Nature

This is a post-peer-review, pre-copyedit version of an article published in Review of Quantitative Finance and Accounting. The final authenticated version is available online at: http://dx.doi.org/ 10.1007/s11156-019-00825-4.

\section{Peer Reviewed}

\section{Repository Citation}

Salavei Bardos, Katsiaryna; Kline, Brandon N.; and Koutmos, Gregory, "Risk Dynamics Around Restatement Announcements" (2019). Business Faculty Publications. 235.

https://digitalcommons.fairfield.edu/business-facultypubs/235

\section{Published Citation}

Bardos, Katsiaryna Salavei, Brandon N. Cline, and Gregory Koutmos. "Risk dynamics around restatement announcements." Review of Quantitative Finance and Accounting (2019): 1-35. https://doi.org/10.1007/ s11156-019-00825-4

This item has been accepted for inclusion in DigitalCommons@Fairfield by an authorized administrator of DigitalCommons@Fairfield. It is brought to you by DigitalCommons@Fairfield with permission from the rightsholder(s) and is protected by copyright and/or related rights. You are free to use this item in any way that is permitted by the copyright and related rights legislation that applies to your use. For other uses, you need to obtain permission from the rights-holder(s) directly, unless additional rights are indicated by a Creative Commons license in the record and/or on the work itself. For more information, please contact digitalcommons@fairfield.edu. 
Published in the Review of Quantitative Finance and Accounting (2019): 1-35. https://doi.org/10.1007/s11156-019-00825-4

\title{
RISK DYNAMICS AROUND RESTATEMENT ANNOUNCEMENTS
}

\author{
Katsiaryna Salavei Bardos \\ Finance Department \\ Fairfield University \\ kbardos@fairfield.edu \\ Brandon N. Cline \\ Finance Department \\ Mississippi State University \\ BCline@business.msstate.edu \\ Gregory Koutmos \\ Gerald M. Levin Professor of Fianance \\ Finance Department \\ Fairfield University \\ gkoutmos@fairfield.edu
}




\title{
RISK DYNAMICS AROUND RESTATEMENT ANNOUNCEMENTS
}

May 9, 2019

\begin{abstract}
:
We investigate the dynamic nature and temporal daily changes in systematic (beta), as well as idiosyncratic and total risk around restatement announcements. We find that beta increases by $51 \%$ at restatement announcement but it reverts to the prerestatement level within one month. However, idiosyncratic risk experiences a longerterm increase of approximately $20 \%$ following a restatement. Cross-sectional analysis shows that the results are more pronounced for restatements associated with irregularity. Overall, our findings suggest that risk components are time-varying with the systematic component rapidly mean-reverting but the idiosyncratic component experiencing a longer-term increase.
\end{abstract}

JEL classification: G14, G30, M41

Keywords: Disclosure, corporate misreporting, financial statement restatements, beta, idiosyncratic risk, EGARCH, cost of capital 


\section{Introduction}

There is a common belief held by firm managers and regulators that higher quality financial information is associated with lower cost of capital. Regulators such as Arthur Levitt, a former chairman of the Securities and Exchange Commission, and Neel Foster, a former member of the Financial Accounting Standards Board, stated that better quality financial information reduces the cost of capital (Levitt 1998; Foster 2003; Lambert et al. 2007). However, there is no consensus in either theoretical or empirical literature regarding whether information risk is systematic or can be diversified away. Moreover, models suggesting that information risk is priced do not agree whether the effect should be concentrated at the time of disclosure or persist in the long-run. We provide new evidence regarding the risk dynamics of firm equity in the context of earnings restatements being a proxy for information risk. Our key finding is that information risk leads to a significant increase in both beta and idiosyncratic risk at the restatement announcement. However, the increase in beta is temporary and persists for only one month, while the increase in idiosyncratic risk is longer-term.

There are several innovations in this paper. First, we examine time variation in both systematic and idiosyncratic risk around restatement announcements. While traditional asset pricing literature focuses mostly on systematic risk on the assumption that it is the only type of risk that is priced, several recent papers suggest that idiosyncratic risk may also be priced (Goyal and Santa-Clara 2003; Xu and Malkiel 2003; and Merton (1987) to mention but a few). For example, Goyal and Santa-Clara (2003) find that there is a tradeoff between risk and return in the stock market and that the risk is measured as total risk, including idiosyncratic risk, rather than only systematic risk. They 
also find that idiosyncratic risk explains most of the variation of average stock risk through time and it is idiosyncratic risk that drives the forecastability of the stock market. Moreover, idiosyncratic risk is important for investors who are not well diversified, as well as arbitrageurs and option traders, whose risk exposure depends on total volatility. Increase in idiosyncratic risk also increases the cost of diversification for investors with limited means (Xu and Malkiel 2003). Merton (1987) argues that idiosyncratic risk should be priced if investors do not hold perfectly diversified portfolios. As such, cross sectional stock returns should be positively related to idiosyncratic risk.

Second, we examine daily changes in the measures of risk using dynamic vector EGARCH with time-varying betas, variances and covariances. Consequently, our paper is the first to isolate the short term effect of restatement announcement on both systematic and idiosyncratic risk, as well as to examine the persistence of changes in these measures. Another advantage of using our methodology is that, unlike commonly used stationary CAPM type models, it accounts for conditional heteroscedasticity of stock returns. It is well known that the returns on speculative assets in general, and stock returns in particular, exhibit widely documented conditional heteroscedasticity, meaning that the second moments and cross-moments are time-varying. Failing to account for such timedependencies when using stationary CAPM type model may lead to erroneous statistical inference.

Our approach allows us to establish several new results. Our findings suggest that idiosyncratic risk increases as early as six months leading up to restatement announcement, spikes at the announcement, then decreases relative to announcement level and remains at elevated levels relative to pre-restatement period for one year 
following the announcement. The increase in beta, however, is only temporary as it experiences a significant increase at restatement announcement but returns to prerestatement level one month after restatement. Changes in measures of risk are both economically and statistically significant. Beta risk increases $51 \%$ from 0.79 the day before restatement to its highest level of 1.19 two days after restatement. Idiosyncratic risk increases $30 \%$ in the same window. Relative to the base period, idiosyncratic risk increases $46 \%$ at the restatement announcement (days $0 ;+5$ ) and remains $21 \%$ higher than the base level one year following a restatement. ${ }^{1}$

Overall, our findings suggest that systematic risk rises temporarily around restatement day. More significantly, we provide new evidence that idiosyncratic risk experiences a longer-term increase following restatement announcement. If idiosyncratic risk is priced as is suggested by recent studies, then this result would indicate a long-term increase in the cost of capital of restating firms due to increase in idiosyncratic risk but not systematic risk. Our results are consistent with the notion that information risk has greater importance for short-term traders, undiversified investors and investors in derivative markets, than for long-term diversified investors. The former group of investors will be affected both by the spike in idiosyncratic risk at the time of the disclosure and by the long-term increase in idiosyncratic risk. Our study is the first to examine the impact of information quality on idiosyncratic risk and the resulting implications for the market participants.

Furthermore, we investigate whether there is cross-sectional variation in changes in equity risk around restatements. We examine whether most of the increase in equity risk is concentrated in restatements with irregularity. Such restatements contain more

\footnotetext{
${ }^{1}$ Base period is defined as a period of six months ending 127 trading days prior to restatement.
} 
information and capture the effect of both poor quality financial information and the effect of fraud, as well as expected litigation and regulatory costs. Restatements that do not involve irregularity isolate the effect of poor quality financial information on risk. We find a significant spike in all measures of risk for both sub-samples, with smaller spike for no-irregularity sub-sample. Beta (idiosyncratic risk) increases by $89.9 \%$ (59.1\%) for irregularity and by $17.9 \%$ (16.7\%) for no-irregularity sub-samples from day -1 to day +2 relative to restatement announcement. However, in cross-sectional analysis that controls for firm size, the difference between the increase in beta at restatement announcement relative to the base level for irregularity and no-irregularity sub-samples is not statistically significant. This difference, however, is significant for idiosyncratic risk. Restatements that involve irregularity are associated with a temporary increase in beta and a long-term increase in idiosyncratic risk. The increase in both beta and idiosyncratic risk is temporary for no-irregularity sub-sample.

Cross-sectional analysis further reveals that restatements of core accounts, such as revenue and cost, result in a similar change in beta and idiosyncratic risk as the non-core restatements at restatement announcement. However, core restatements have larger increases in beta and idiosyncratic risk one year after restatement. All measures of risk increase more at restatement announcement for restatements made by larger firms. We find that it matters whether restatements are initiated by SEC, auditor or the company and whether the restatement is made more than once by the same company. We also find that there is a negative relation between the announcement period return and the idiosyncratic risk, suggesting that idiosyncratic risk is priced. 
Our paper differs in important ways from other research on restatements and equity risk. Bardos (2011) and Badertscher and Burks (2010) find that restating firms experience an increase in Amihud's (2002) measure of illiquidity following restatement announcements, suggesting an increase in information asymmetry. Palmrose et al. (2004) document an increase in the dispersion of analyst forecasts following restatement announcements. However, they find no evidence of change in the bid-ask spread subsequent to restatements. Although both bid-ask spread and the change in analyst forecasts are associated with firm's equity risk, neither represents a good proxy for risk facing the long-term investor (Hribar and Jenkins 2004; Callahan et al. 1997). Wilson (2008) analyzes changes in earnings response coefficients (ERCs) subsequent to the restatement relative to ERC estimated five quarters before restatement announcement and find that informational content of ERCs decreases only temporarily for two to three quarters following the restatement announcement. However, as shown by Bardos et al. (2011), ERCs prior to restatement announcement are a function of accounting mistakes and therefore are not a reliable benchmark. Moreover, since several studies show that analysts are slow to adjust their recommendations following restatements and other major announcements (Griffin 2003; Kasznik 2004), Wilson's earnings response coefficients are calculated using potentially biased analyst forecasts.

Hribar and Jenkins (2004) estimate the impact of restatements on the firm's cost of equity using an implied cost of capital technique. They estimate the change in the cost of capital one, three, and five months after the restatement and find that the cost of capital increases following a restatement. The authors conclude that their evidence is consistent with accounting restatements increasing investors' required rates of return. However, 
application of implied cost of capital methodology to an event study such as restatements makes the results particularly sensitive to biases in analyst forecasts, casting doubts on the robustness of Hribar and Jenkins's (2004) results. In the discussion of this paper, Kasznik (2004) points out that the well-documented analyst under-reaction to adverse earnings information may bias cost of capital estimates upward.

Kravet and Shevlin (2010) examine changes in the loadings on the information risk factor before and after restatement announcements, which is based on how well working capital accruals map into cash flows. They do so by including the information risk factor as an additional term in the Fama and French (1993) model and find an increase in the factor loadings on the discretionary information risk factor after the restatement announcement. They also find a statistically insignificant decrease in beta following restatement. There are several potential issues with their methodology. First, it assumes that information risk is an additional risk factor, relying on theoretical model of Easley and O'Hara (2004). However, more recent theoretical work finds that information risk manifests itself in higher market beta rather than an additional factor (Hughes et al. 2007; Lambert et al. 2007; and Christensen et al. 2010). Moreover, for restating firms they calculate the information risk factor prior to the restatement announcement using figures that contain material accounting mistakes. Therefore, the difference in loadings can potentially be attributed to mistakes in financial reports before restatement rather than changes in pricing.

Furthermore, the methodology in Kravet and Shevlin (2010) and Hribar and Jenkins's (2004) does not allow for testing the prediction of Christensen et al. (2010) that most of the change in information risk is concentrated at the announcement. Our 
methodology estimates daily changes in beta, thus making it possible to estimate the effect of the restatement announcement on the firm's risk along with the evolution of changes in the risk measures. To the best of our knowledge, our paper is the first to study daily changes in firm risk and its association with information quality. Moreover, no prior study has examined changes in idiosyncratic risk around restatements.

The paper proceeds as follows. The next section reviews in detail related literature. Section 3 discusses our methodology. Section 4 describes the data. Results and their interpretation are presented in Section 5. Section 6 concludes the paper.

\section{Related literature}

Early theoretical models in accounting literature which specifically model the relation between firm's disclosure and the cost of capital analyzed a single-firm setting. ${ }^{2}$ However, the single-firm setting does not allow differentiation between systematic and idiosyncratic risks since. In a recent study, Easley and O'Hara (2004) develop a multiasset rational expectations asset pricing model, in which private information increases the uninformed investor's risk. They show that the mix between public and private information impacts the cost of capital, as investors demand higher returns for holding stocks containing larger amounts of private information. Investors require higher premiums because private information increases the risk to uninformed investors since informed investors are better able to shift their portfolio weights to incorporate new information. Easley and O'Hara's (2004) model implies that information asymmetry generates a new form of systematic risk which is reflected in the risk premium. Thus, they establish an indirect link between information and the cost of capital, namely better

\footnotetext{
${ }^{2}$ See Verrecchia (2001) for literature review.
} 
quality of financial information reduces both information asymmetry and adverse selection, which in turn lowers the cost of capital. However, their model assumes that future values of risky stocks are not correlated (they are independently normally distributed) and that investors are exogenously endowed with a limited set of securities. Therefore, the model does not account for the effects of diversification.

Using a framework similar to that of Easley and O'Hara (2004), Hughes et al. (2007) examine the relation between asymmetric information and the cost of capital utilizing a noisy rational expectations model with two classes of investors, informed and uninformed. In contrast to Easley and O'Hara (2004), they find that information from private signals about idiosyncratic shocks is idiosyncratic and therefore has no effect on the cost of capital. Their analysis differs from Easley and O'Hara's (2004) in two ways. First, they examine large economies, which allow for full diversification, while Easley and O'Hara (2004) consider only finite economies. Second, they assume factor structure as in Ross's (1976) Arbitrage Pricing Theory for both private signals and asset payoffs.

Lambert et al. (2007) analyze the relation between information risk and the cost of capital using a CAPM type model with only public information and multiple securities, the payoffs of which are correlated. They show that better quality firm-specific disclosures reduces the cost of capital. Furthermore, this information effect is nondiversifiable since it affects the firm's assessed covariances with other firms' cash flows and is present for all covariance terms. Based on these results, Lambert et al. (2007) conclude that the best way to empirically analyze the link between information quality and the cost of capital is via the beta factor. ${ }^{3}$ The findings of Lambert et al. (2007) that

\footnotetext{
${ }^{3}$ Their results do not provide support for an information risk factor over and above beta as suggested by Easley and O'Hara (2004), unless that factor captures measurement error in beta.
} 
information risk is priced contradicts Hughes et al. (2007) claim that information risk is fully diversifiable. Lambert et al. (2007) attribute the difference in result to a different definition of the cost of capital, and state that when they translate results from Hughes et al. (2007) into their definition of the cost of capital, they continue to find that information risk is priced. ${ }^{4}$

In a recent study, Christensen et al. (2010) argue that the decrease in the cost of capital after release of more precise information (as shown by Lambert et al. 2007) is temporal and is entirely offset by the increase in the cost of capital prior to the release of information. As a result, information risk has no effect on the ex ante cost of capital covering the full span of the firm. Christensen et al. (2010) analyze a two period model with one risky asset and both public and private information. However, they argue that results hold in a more general setting with multiple risky assets and multiple periods. A limiting assumption of Christensen et al. (2010) is that the information system has no impact on capital investment and other production choices. ${ }^{5}$ Moreover, the results of the model might not hold if investors have non-time-additive preferences.

Empirical tests of the impact of disclosure quality on risk critically depend on the measure of disclosure quality and the measure of the cost of capital (Leuz and Wysocki 2015). A large body of literature examines cross-sectional association between disclosure quality and the cost of capital. To measure information quality, several studies used CFA Institute (formerly Association for Investment and Management Research (AIMR)) scores composed by financial analysts that evaluate firm disclosure based on annual,

\footnotetext{
${ }^{4}$ Hughes et al. (2007) define the cost of capital as the difference between beginning-of-period price and end-of-period expected cash flows, while Lambert et al. (2007) define cost of capital as the expected rate of return on the firm's stock.

${ }^{5}$ Lambert et al. (2007) do not explicitly model firm's production decision and capital raising needs, but do consider effect of disclosure on real decision (Indjejikian 2007).
} 
quarterly and other published information, along with communications with analysts (Botosan and Plumlee 2002). However, AIMR scores suffer from several biases and were available only for large U.S. firms during the 1980s and 1990s. Other studies construct an index of disclosure in firm's annual reports (Botosan 1997; Botosan 2006; Hail 2003; and Francis et al. 2008). The problem with such indices is that they focus exclusively on annual reports and ignore other forms of disclosure, capturing the existence of certain disclosures rather than disclosure quality (Leuz and Wysocki 2015). These papers find negative association between quality of disclosure and the cost of capital for at least a sub-sample of firms. Richardson (2000) finds that there is a systematic relationship between the magnitude of information asymmetry and the level of earnings management.

Recent studies use earnings quality measures, mainly based on models of accruals quality ala Dechow and Dichev (2002), to proxy for information quality (Francis et al. 2004, 2005; Francis et al. 2008; Verdi 2006; Ogneva 2007; Ecker et al. 2006) and find that better quality financial information reduces the cost of capital. Another concern with aforementioned studies is the limitations of the measure of the cost of capital and the shortcomings of the research design. Several studies use implied cost of capital methodology to estimate the cost of capital, which measures the cost of capital as a discount rate that makes the stock price equal to the discounted present value of future cash flows. ${ }^{6}$ The primary drawback to this methodology is that it relies on analyst forecasts of future performance. Easton and Sommers (2007) illustrate that upward biases occur in implied cost of capital due to overoptimistic analyst forecasts. Hughes et al. (2009) demonstrate that implied cost of capital differs from expected return, by a function

\footnotetext{
${ }^{6}$ Botosan (1997), Botosan and Plumlee (2002), Francis et al. (2004, 2005), Francis et al. (2008), among others, use implied cost of capital methodology.
} 
encompassing volatilities of, as well as correlation between, expected returns and cash flows, growth in cash flows, and leverage. They express the concern that empirical relations documented using implied cost of capital are attributable to this difference. Moreover, Core et al. (2008) show that contemporaneous regressions of asset returns on factor returns, which include accruals quality as a separate factor such as those in Francis et al. (2004, 2005), are not well specified and that the relation between returns and accrual quality disappears when proper asset pricing tests are employed. Core et al. (2008) further show that daily hedge portfolio evidence in Ecker et al. (2006) and Nichols (2006) appears to be misspecified.

Several other studies analyze the association between disclosure and the cost of capital in the event-study setting rather than using cross-sectional framework. Schrand and Verrecchia (2005) and Leone et al. (2007) find that better pre-IPO disclosure is associated with lower under-pricing. Graham et al. (2008) find that the cost of debt increases following a restatement announcement. Hribar and Jenkins (2004) find an increase in the implied cost of capital technique following restatements. Ye and $\mathrm{Yu}$ (2018) examine whether restatements affect trading volume reactions to subsequent earnings announcements. They find that restatements increase the degree of differential event-period information, leading to more divergent interpretation of earnings announcements subsequent to restatements.

Gleason et al., (2008) show an information transfer effect for non-restatement firms. They find that accounting restatements that result in negative market reaction at the announcement of the restatement cause stock price declines among non- restating firms in the same industry, particularly those with high industry-adjusted accruals. This result is 
concentrated in revenue restatements by large firms, as well as for peer firms with high earnings and high accruals when restating firm a peer firm use the same external auditor. $\mathrm{Xu}$ et al. (2006) also examine intra industry effects of accounting restatements and find no significant change in risk of the rival firms, suggesting that a firm's earnings restatement does not have a long-lasting impact on inventors' confidence in the earnings quality of the rival firms. Other studies examine timeliness of financial information disclosures in the context of the efficient market hypothesis (Huang et al. 2017; and Yen and Lee 2008). Yu and Chen (2017) argue that in deciding how much customer information to disclose, managers face a tradeoff between the benefits of reducing information asymmetry and the losses of revealing proprietary information. Tuo et al. (2019) find that disclosure strategies of individual firms are significantly influenced by their peer firms' disclosure behaviors.

In summary, the empirical literature on the cross-sectional association of the quality of financial information and the cost of capital is inconclusive and is sensitive to alternative research design. More importantly, almost all of the aforementioned studies fail to investigate the dynamic nature of the risk components, i.e., systematic and idiosyncratic risk. Most of the disagreements in the empirical findings are related to the behavior of systematic risk surrounding the particular event, but no attention is being paid to idiosyncratic risk.

Restatements provide a unique opportunity to study the dynamic nature of the risk components of restating firms because ex post one can identify a period during which publically available financial information contained material mistakes (we call this window the error period). Moreover, ex post one can identify the size and the nature of 
the mistakes. Therefore, we can use observable characteristics of the quality of financial reporting rather than noisy proxies. Furthermore, we can use the firm as its own control and consequently avoid omitted variable and endogeneity problems that arise when one attempts to control for the determinants of disclosure quality. A number of papers show that accruals measure of disclosure quality has many shortcomings (Banker et al. 2019).

\section{Measures of equity risk: the dynamic market model}

Bardos at el. (2011) show that investors are misled by material mistakes in financial statements for most of the error period, which starts with the first restated report and ends with the restatement announcement. ${ }^{7}$ Since investors are misled by material mistakes, restatements of financials signal to the market poor quality of previously reported financial information as well as raise concern regarding the quality of future reports. The theoretical model of Lambert et al. (2007) implies a permanent increase in beta for restating firms. If information risk is priced, then we should observe an increase in beta at restatement announcement that persists after restatement. In light of the findings of Bardos et al. (2011), who find that the marginal investor anticipates restatements three months prior to its announcement it is possible that beta increases before restatement due to its anticipation. Our research design also allows us to test whether changes in the components of risk around disclosure are temporal since we are able to estimate daily changes in both systematic and idiosyncratic risk. Restatements present a particularly good setting to test for such changes because they are unscheduled events and therefore the pre-announcement period does not overlap with post-

\footnotetext{
${ }^{7}$ Note that the average length of the error period in their study is about two years.
} 
announcement period from prior announcement of the same type, which would be the case for earnings announcements or other regularly scheduled disclosure events.

To examine the dynamic nature of systematic (beta) and idiosyncratic risk, we use a bivariate Exponential GARCH (EGARCH) model with time-varying betas, variances and covariances. ${ }^{8}$ We estimate the model over the period of three years before and three years after the restatement announcement. ${ }^{9}$ The advantage of this model is that we obtain daily estimates of beta, systematic risk and idiosyncratic risk ${ }^{10}$. The dynamic bivariate EGARCH market model can be described by the following set of equations:

$$
\begin{aligned}
& R_{i, t}=c_{i}+\beta_{i, t} R_{m, t}+\varepsilon_{i, t} \\
& R_{m, t}=c_{m}+\varepsilon_{m, t}
\end{aligned}
$$

where $R_{i, t}$ and $R_{m, t}$ are the daily returns on the individual security and the market portfolio respectively; $\beta_{i, t}$ is the time-varying security beta; $c_{i, t}$ and $c_{m, t}$ are constants and; $\varepsilon_{i, t}$ and $\varepsilon_{m, t}$ are innovations or, error terms for the individual security and the market respectively.

The elements of the variance/covariance matrix of the two error terms follow a bivariate EGARCH model described by the following set of equations:

$$
\begin{gathered}
\sigma^{2}\left[\varepsilon_{i, t}\right]=\exp \left\{\alpha_{i, 0}+\alpha_{i, 1}\left(\left|z_{i, t-1}\right|-E\left|z_{i, t-1}\right|+\delta_{i} z_{i, t-1}\right)+\varphi_{i} \ln \left(\sigma^{2}\left[\varepsilon_{i, t-1}\right]\right)\right\} \\
\sigma^{2}\left[\varepsilon_{m, t}\right]=\exp \left\{\alpha_{m, 0}+\alpha_{m, 1}\left(\left|z_{m, t-1}\right|-E\left|z_{m, t-1}\right|+\delta_{m} z_{m, t-1}\right)+\varphi_{m} \ln \left(\sigma^{2}\left[\varepsilon_{m, t-1}\right]\right\}\right. \\
\sigma_{i, m, t}=\rho_{i, m}\left(\sigma^{2}\left[\varepsilon_{i, t}\right] \sigma^{2}\left[\varepsilon_{m, t}\right]\right)^{1 / 2}
\end{gathered}
$$

where, $\ln ($.$) are natural logarithms, z_{i, t}=\varepsilon_{i, t} \sigma\left[\varepsilon_{i, t}\right]$ and $z_{m, t}=\varepsilon_{m, t} \sigma\left[\varepsilon_{m, t}\right]$ are normalized innovations; $\sigma_{i, m, t}$ and $\rho_{i, m}$ are the conditional covariance and the conditional correlation;

\footnotetext{
${ }^{8}$ A number of papers discusses the sensitivity of the results to beta estimation (Gong et al. 2006).

${ }^{9}$ Not all firms have return data for the entire time period. We require firms to have at least six months of data prior to mistake so that firm performance before material mistakes in financial statements can serve as a benchmark.

${ }^{10}$ To our knowledge this is the first study to examine the behavior of idiosyncratic risk during restatements.
} 
and $\alpha_{i, 0}, \alpha_{i, 1}, \delta_{i}, \varphi_{i}, \alpha_{m, 0}, \alpha_{m, 1}, \delta_{m}, \varphi_{m}$ are fixed parameters to be estimated. The univariate EGARCH model was introduced by Nelson (1991) as a way of modeling time-varying volatilities for speculative assets. Compared to standard GARCH models it has several advantages. First, it does not require non-negativity constraints for the parameters since it imposes the non-negativity constraint in the variance directly. Second, it can accommodate asymmetric responses of the variance to positive and negative innovations, a phenomenon frequently observed in the stock markets. Third, it allows for oscillatory behavior of the variance. Negative values for $\delta_{i}$ and $\delta_{m}$ would imply that negative returns are followed by higher volatility than positive returns of an equal size. The degree of volatility persistence is captured by parameters $\varphi_{i}$ and $\varphi_{m}{ }^{11}$ The beta of the individual security is given by

$$
\beta_{i, t}=\left(\sigma_{i, m, t} / \sigma^{2}\left[\varepsilon_{m, t}\right]\right)
$$

Equation (1) implies that $\sigma\left[R_{i, t}\right]=\left(\beta_{i, t}^{2} \sigma^{2}\left[\varepsilon_{m, t}\right]+\sigma^{2}\left[\varepsilon_{i, t}\right]\right)^{1 / 2}$. Furthermore, the total standard deviation can be decomposed into its systematic part and its idiosyncratic part, in terms of $\beta_{i, t}$, as follows:

$$
\sigma\left[R_{i, t}\right]=\beta_{i, t} \sigma\left[\varepsilon_{m, t}\right]+\left\{\sigma\left[R_{i, t}\right]-\beta_{i, t} \sigma\left[\varepsilon_{m, t}\right]\right\}
$$

where $\beta_{i, t} \sigma\left[\varepsilon_{m, t}\right]$ and $\left\{\sigma\left[R_{i, t}\right]-\beta_{i, t} \sigma\left[\varepsilon_{m, t}\right]\right\}$, represents systematic risk and idiosyncratic risk respectively. ${ }^{12}$

We estimate the fixed parameters of the model using Quasi Maximum Likelihood and maximizing the sample log-likelihood function of the form:

$$
L(\Theta)=-T \log (2 \pi)-(1 / 2) \Sigma_{t}\left(\log / H_{t} /+E_{t} H^{-1} E^{\prime}\right),
$$

where, $T$ is the number of observations, $\Theta$ is the parameter vector to be estimated, $E_{t}=\left[\varepsilon_{i, t}\right.$ $\left.\varepsilon_{m, t}\right]$ is the $1 \times 2$ vector of innovations at time $\mathrm{t}, H_{t}=\operatorname{Cov}\left(E_{t} / I_{t-1}\right)$, is the time-varying

${ }^{11}$ See Koutmos and Booth (1995) for further details on the multivariate EGARCH model.

${ }^{12}$ We will be referring to beta and systematic risk interchangeably. 
covariance matrix. The diagonal elements of $H_{t}$ are given by (3) and (4) and the cross diagonal elements are given by (5). We obtain consistent standard errors following Bollerslev and Wooldridge (1992). Because of nonlinearities in the log-likelihood function, numerical maximization techniques are used to obtain parameter estimates. The particular algorithm used is based on Berndt et al. (1974). In estimating the model, we pair each company with the market portfolio and we obtain estimates of the fixed parameters as well as time-series estimates of the time-varying parameters $\beta_{i, t}, \sigma^{2}\left[\varepsilon_{i, t}\right], \sigma^{2}\left[\varepsilon_{m, t}\right]$ and $\sigma_{i, m, t-1}$.

\section{Data}

This study analyzes a sample of restatements announced between January 1, 1997 and June 30, 2002. Since our objective is to examine changes in risk around serious material reporting violations, we focus on the period prior to enactment of SarbanesOxley act (SOX) because following SOX, restatements became more technical (Burks (2011)). In this paper we use the sample of restatements used by Bardos et al. (2011). The advantage of the sample is that it is hand collected and carefully constructed focusing on mistakes, rather than changes in accounting, and thus avoids potential problems as those discussed in Karpoff at el (2017).

We focus only on annual restatements, which involve restatement of at least one annual report. For such restatements, financial statements with material mistakes have been audited, while for restatements of only quarterly reports mistakes have been uncovered before the audit. ${ }^{13}$ This suggests that annual restatements represent cases of poorer quality of financial information. Moreover, Bardos et al. (2011) find that investors

\footnotetext{
${ }^{13}$ Annual restatements involve amendments of potentially all quarterly reports, not just the forth quarter. The key difference between annual restatements is that they are made after the audit of financial statements.
} 
are misled by annual restatements and are not misled by restatements of only quarterly reports.

Restatement dates and restatement characteristics are hand collected from the Lexis-Nexis and Factiva databases. The Lexis-Nexis and Factiva databases are researched using key words "restatement," "restat," "revis," “adjust," “error" and "responding to guidance from the SEC" for the period January 1, 1997 through June 30, 2002. We identified 923 restatement announcements between 1997 and 2002 and crosschecked these announcements with the sample released by Government Accountability Office (GAO, 2002). Following Bardos et al. (2011), we excluded 130 restatements which were caused by the adoption of new accounting rules or changes in accounting methods since our focus is on the effect of quality of financial information on risk, rather than the impact of changes in accounting rules. This mitigates the main issue identified by Dechow et al. (2010) with using restatements as a proxy for earnings quality. We lose remaining observations due to missing data in either CRSP or COMPUSTAT, or due to missing information about the restatement itself. The final sample includes 536 restatements from 496 firms. The sample includes 330 annual restatements, of which 247 are income decreasing. To arrive at our final sample of 143 restatements made by 137 firms, we retained firms with at least six months of returns prior to mistake through restatement announcement, ${ }^{14}$ with non-missing data on size the year before restatement announcement. We require firms to have at least six months of data prior to mistake so that firm performance before material mistakes in financial statements can serve as a benchmark.

\footnotetext{
${ }^{14}$ For an average firm in our sample the distance from mistake to restatement is two years.
} 
Table 1 reports descriptive statistics for our sample. The mean market capitalization for our sample is 3.3 billion, with the median of 248 million. Average value of total assets is higher and equals 4.2 billion. The average leverage equals $20 \%$. Restating firms amend 2.3 years, on average. Consistent with prior studies, we find that restatements are associated with a negative abnormal stock price decline of $-9 \%$ as measured by CAR01. Abnormal return (CAR01) is defined as a market model cumulative abnormal return for days zero and plus one relative to a restatement announcement. Market model parameters are estimated over a 250 day period starting on day -46 relative to restatement using value weighted market index. ${ }^{15}$ The mean (median) Change in NI equals $-43 \%(-2 \%)$ of total assets, with the mean of only $2 \%$. Change in NI is the difference between restated Net Income and originally reported Net Income divided by total assets reported in the year preceding restatement announcement. If more than one period is restated, Net Income for all restated periods is added up. For only five percent of restatements net income crosses the loss threshold.

We separately analyze restatements with and without irregularity. For a sample of firms without irregularity, restatement announcement will signal only poor quality financial information. The irregularity sub-sample will reflect the effect of both poor information quality and fraud on firms' risk. Following Palmrose et al. (2004) and Hennes et al. (2008) we define Irregularity as a dummy that equals one if the company announced fraud or an irregularity as a reason for restatement or if restating firm was subject to Accounting and Auditing Enforcement Releases (AAERs) as a result of a restatement. About $36 \%$ of restatements in our sample are due to irregularity. Forty three

\footnotetext{
${ }^{15}$ We use standard methodology employed in other studies, rather than EGARCH, to calculate CAR01 so that we can compare our sample to that used in prior studies. CAR01 is reported only for descriptive purposes and is not central to our study.
} 
percent of restatements involve core accounts, such as revenue and cost. We also separate restatements that provide full information about corrected statements and the ones they do not provide all of the details (No detail). $57 \%$ of restatements provide no details at restatement announcement. We also separate between restatements initiated by different parties, such as SEC, Company and Auditor. The majority of restatements are initiated by the company (49\%), with $32 \%$ initiated by the SEC and $11 \%$ by the auditor.

\section{Results}

\subsection{Changes in measures of risk around restatement announcement}

We first depict trends in systematic, idiosyncratic and total risk for the full sample 250 trading days before and after restatement announcement (Figure 1 and Table 2). We estimate a series of bivariate EGARCH models to obtain estimates of the risk components specific to each firm, and then average the firm-specific estimates across firms in order to create the Figures. Recall that systematic risk is measured by beta, which is given in equation (6), and idiosyncratic and total risk is given in equation (7). Beta experiences a slight upward trend in the year leading to the announcement. A significant spike occurs immediately after the announcement, followed by a gradual decline. Idiosyncratic risk increases gradually in the year leading to the announcement, displaying a sharp increase in the week prior, followed by a sharp increase immediately after the announcement and a gradual decline to what appears to be a sustained higher level of idiosyncratic risk. A similar pattern is observed for total risk. We find that idiosyncratic risk has a higher persistence after restatement announcement while beta reverts faster to a slightly higher level than before restatement. 
Table 2 shows descriptive statistics for trends observed in Figure 1. It confirms that the spike in all measures of risk is economically significant: beta spikes $43 \%$ relative to base period, i.e., a six months window ending on day 127 prior to restatement announcement. Idiosyncratic risk increases $46 \%$ at restatement announcement. All measures of risk remain high one month and one year after restatement. Beta is $23 \%$ higher one month after restatement (window $(+6 ;+26)$ ) than during the base period and is $8 \%$ higher one year following a restatement (window $(+27 ;+250)$ ). Idiosyncratic risk remains higher than beta relative to the base level $-37 \%$ higher one month after restatement and $21 \%$ higher one year after restatement.

In Table 3, we test statistical significance of trends depicted in Figure 1 and Table 2. Using a panel regression approach, we regress measures of risk on restatement announcement and post-restatement time dummies. To account for residual dependence created by firm and time effects we cluster standard errors by restatement. Petersen (2009) shows that only clustered standard errors are unbiased and correctly account for the dependence in the presence of fixed firm effects. Clustering solely by restatement is sufficient when there are only few clusters on time dimension, as is the case in our study. ${ }^{16}$

To decide which time dummies to include in Table 3 panel regression, we examine trends in all risk measures for 250 days before and after the restatement. Figure 1 reveals that there is an upward trend in all measures of risk prior to restatement announcement; therefore, we include a dummy for six months before restatement announcement for all measures of risk. For beta we include a dummy for 120 trading

\footnotetext{
${ }^{16}$ We analyze restatements announced during a 5 year window. Petersen (2009) considers 10 year clusters to be small.
} 
days before restatement $(-120 ;-1)$ only (with the coefficient labeled b1). For total and idiosyncratic risk we observe a spike about one week before restatement. Therefore, we include time dummies for 120 trading days before restatement, starting on day -6 (-126; $6)$, and for a five trading day window prior to restatement $(-5 ;-1)$ for total and idiosyncratic risk. Coefficients on these dummies are labeled b1 and b1', respectively. To estimate the effect of restatement announcement on risk, we include a time dummy for window $(0 ;+5)$ with the estimated coefficient of b2. Figure 1 shows that the increase in total, systematic and idiosyncratic risk, as well as increase in beta persist after restatement announcement and is particularly pronounced during the month following a restatement. To test whether increase in measures of risk persists both in the short and the long run, we include a dummy for the month following a restatement (window $(+6 ;+26)$ ) and a dummy for the rest of the year following a restatement $(+27 ;+250)$. We label coefficients on these dummies b3 and b4, respectively. The intercept in Tables 3-6 reflects the baseline of days $(-250 ; 119)$.

Table 3 shows that trends depicted in Figure 1 are statistically significant. Beta spikes at restatement announcement and remains at elevated levels one month following restatement. Note that the coefficient on b2 (restatement announcement window of ( 0 ; $+5)$ ) is much higher than all other coefficients, confirming a substantial spike. The coefficient b3 (window $(+6 ;+26)$ ) is about half the size of b2 and is also highly significant, suggesting that beta remains elevated one month after restatement announcement. Unlike in the case of total and idiosyncratic risks, which begin increasing about one year before restatement, firm's beta starts increasing only one week before restatement (b1 is not significant for beta regression). Similarly, coefficient on dummy 
$(+6 ;+250)$ is not significant for beta, while it is significant for other measures of risk. The results suggest that restatements cause a significant spike in beta but that the effect of restatement on beta is temporary.

Table 3 confirms that idiosyncratic and total risks begin increasing before restatement (particularly one week before), peek at restatement announcement and remain at elevated levels one year following restatement as suggested by significant coefficients on all time dummies. The increase is the greatest at the restatement announcement and one month after restatement. For total risk, all coefficients on time dummies are different from each other except for b1' and b4 - coefficients on a dummy for one week period before restatement $(-5,-1)$ and a dummy for post-restatement period $(+27 ;+250)$, respectively. This suggests that total risk increases about half a year prior to restatement, increases further one week prior to restatement, spikes at restatement announcement, declines after restatement announcement for about one month and remains at the level it has been one week prior to restatement for the rest of the postrestatement period. For idiosyncratic risk we find very similar results, except that the coefficient for b1 and b4 are not different from each other, suggesting that idiosyncratic risk after restatement in window $(+27 ;+250)$ is of the same level as six months before restatement during window $(-120 ;-6)$.

Overall, our findings suggest that systematic risk is experiencing a temporary increase due to restatement. Specifically, beta increases $43 \%$ at restatement announcement relative to base period and remains at elevated levels one month after restatement. However, it returns to the pre-restatement level thereafter. This result is in agreement with Christensen et al. (2010). We also find that idiosyncratic risk experiences 
a $46 \%$ increase at restatement announcement and remains $21 \%$ higher than the base level one year after restatement, suggesting a long-term increase in idiosyncratic risk.

\subsection{Results by characteristic of restatement and restating firms}

\subsubsection{Irregularity versus no-irregularity restatements}

In this section we study changes in risk for different sub-samples of restatements. First, we examine whether changes in risk differ for sub-samples with and without irregularity. Restatements due to irregularity reveal both poorer quality of financial information and greater uncertainty regarding firms' management and its integrity. Therefore, a sub-sample of restatements with irregularity will capture both the effect of poor quality information and the effect of fraud on risk. Restatements that are not due to fraud are of particular interest since in this sample the effect of poor quality of financial statements on risk is isolated. We define restatements due to irregularity using an approach along the lines of Palmrose et al. (2004) and Hennes et al. (2008) as restatements subject to SEC enforcement actions (AAER) and as restatements that disclose irregularity or fraud as the reason for restatement. As shown in Table 1, Panel C, $36 \%$ of our sample of restatements involves irregularity.

Figure 2 and Table 4 show that, as expected, the change in all measures of risk is greater at restatement announcement and one month following restatement due to irregularity. For the irregularity sub-sample, beta spikes from 0.89 the day before restatement to its highest level of 1.69 two days after restatements (an increase of 90\%) and gradually declines to pre-restatement level (as suggested by insignificant coefficient on b4 $(+27 ;+250)$ window dummy). Although an increase in beta at restatement 
announcement of no-irregularity sub-sample is not as pronounced, it is also statistically significant. The beta increases $18 \%$ from 0.76 on day -1 to its highest point of 0.89 on day +2 for no-irregularity sub-sample. For both sub-samples beta returns to prerestatement level.

Idiosyncratic risk increases six months before restatement, increases further one week before restatement, increases $59.1 \%$ for irregularly and $16.7 \%$ for no-irregularity sub-samples from day -1 to day +2 , respectively (Figure $2 \mathrm{c}$ ). All increases are statistically significant as shown in Table 4, Panel B (coefficients on b1, b1' and b2 are statistically significant and different from each other). Idiosyncratic risk remains at elevated level one month after restatement for both sub-samples. Interestingly, the increase in idiosyncratic risk is significant only for irregularity sub-sample: idiosyncratic risk one year after restatement remains at the same elevated level it reaches one week prior to restatement $(\mathrm{b} 1$ '=b4). For no-irregularity sub-sample, idiosyncratic risk returns to pre-restatement level one month after restatement since coefficient on b4 is not significant. Increases in total risk are significant for all sub-periods for both sub-samples.

Overall our results suggest that poor quality financial information, even in the absence of irregularity, increases firm beta and idiosyncratic risk at restatement announcement and one month after restatement. Restatements that involve irregularity cause temporary increase in beta and a long-term increase in idiosyncratic risk. Noirregularity restatements cause only temporary increase in both beta and idiosyncratic risk. 


\subsubsection{Core versus non-core restatements}

We also separately analyze restatements due to corrections of core and non-core accounts. We define core restatements as those involving revenue, cost of sales or operating expense accounts for on-going operations to control for the seriousness of the restatement. In our sample, restating firms also amend non-core accounts such as securities-related items (e.g., accounting for derivatives, warrants, stock options and convertible securities), in-process research and development (IPR\&D), reclassifications and related party transactions. Previous research finds that more persistent operating income is associated with stronger market reactions (Kormendi and Lipe 1987). Several studies have also shown that the market reacts more strongly to surprises in on-going operating income than to one-time special items (Elliott and Hanna 1996; Strong and Meyer 1987). Therefore, restatement of non-core items can have smaller effect on firm risk because ax ante market expects non-core accounts to be recorded with less precision. Recall that forty three percent of our sample of restatements affect core accounts.

Figure 3 and Table 5 show the analysis of the trends in risk for these sub-samples. Interestingly, beta increases more for non-core than for core sub-sample: the increase from day -1 to day +2 equals $57.5 \%$ and $17.9 \%$, respectively. Similarly, idiosyncratic and total risks increase more for non-core sub-sample. Idiosyncratic risk increases $31.7 \%$ for non-core and $16.7 \%$ for core sub-samples from day -1 to day +2 . Table 5, Panel A shows that increase in beta at restatement announcement and one month after restatement are statistically significant for both sub-samples. Trends in idiosyncratic and total risk are similar for core and non-core sub-samples and the full sample except for the fact that for both sub-samples coefficient b4 on window $(+27 ;+250)$ is not significant in idiosyncratic 
risk regression, suggesting that it returns to base level after restatement. As a result, total risk increases after restatement only for core sample. Overall, this analysis suggests that non-core restatements increase risk more than core restatements. This result is particularly interesting in light of the findings of Palmrose et al. (2004) that restatements of core accounts are not associated with abnormal returns at restatement announcement, controlling for other determinants of the returns.

\subsubsection{Large versus small firms}

Next, we analyze whether the change in risk around restatement announcement is different for large and small firms. Large firms have been shown to have lower information asymmetry due to greater analyst and media coverage (Frankel and Li 2004; Healy and Palepu 2001). Moreover, large and small firms have different composition of risk, with large firms having less total risk. Several studies show that new information released by large firms has spill over affects on other firms in the industry and that larger firms tend to announce earnings earlier than smaller firms (Ramnath 2002; Han and Wild 1990). Moreover, large firms tend to implement long-term performance plans that reduce the level of earnings management (Richardson and Waegelein 2002). Large firms also end to have more institutional investors and it has been shown that institutional investors' presence acts as a monitor on target firms' use of real earnings manipulation activities (Sakaki et al. 2017). Therefore, we expect that firm specific information released by larger firms at restatement announcement is likely to affect covariance with other firms in the industry and as a result increase systematic risk more for such firms. 
We find results consistent with this prediction (see Figure 4 and Table 6). Large (small) firms are defined as above (below) mean logarithm of market capitalization measured at fiscal year end before restatement announcement. Beta increases more for large firms than for small firms (Figure $4 \mathrm{a}$ and Figure $4 \mathrm{~b}$ ), while increase in idiosyncratic risk is of similar magnitude for large and small firms (Figure 4c). Consistent with results for the full sample, beta increases only at restatement announcement and remains high one month after restatement for both small and large firms. Both total risk and idiosyncratic risk increase six months before restatement announcement for small and large firms. Overall, consistent with asset pricing literature we find that small firms have more total risk and more idiosyncratic risk, but have less systematic risk than large firms.

\subsubsection{Restatements initiated by SEC, Auditor and Company}

Next, we analyze whether the change in risk around restatement announcement depends on who initiated the restatement. We distinguish between restatements initiated by SEC, auditor and company. We expect that if restatement is initiated by the SEC and auditor there will be more uncertainty in the market and the risk measures will increase more. Palmrose et al. (2004) find a more negative market reaction, respectively, associated with restatements initiated by the auditor. Hribar and Jenkins (2004) show that restatements initiated by auditor have the greatest increase in the and higher implied cost of capital following restatement announcement. Kravet and Shevlin (2010) find that restatement initiator affects the change in the pricing of discretionary information risk.

Figure 5 shows that firms whose restatements are initiated by the SEC have higher beta but lower idiosyncratic risk the year prior to restatement. Their total risk is 
also lower during this period. These firms see a spike in all measures of risk at the announcement of restatement. Beta increases from 0.94 the day before restatement announcement to 1.17 on the second day after restatement announcement representing a $24 \%$ increase. Unsystematic risk increases $29 \%$. Table 7 confirms that the increase in all measures of risk for restatements initiated by SEC are higher at restatement announcement. We find that the coefficient on b3 is statistically significant in Table 7 Panel A, but the coefficient on b4 is not statistically significant. This suggests that the beta returns to the base level one months after restatement announcement. At the same time, we find that the coefficient on b4 is statistically significant in Table 7 Panel B, suggesting that idiosyncratic risk increases for a year after restatement announcement. We also find that coefficient $\mathrm{b} 1$ is less than $\mathrm{b} 4$, suggesting that idiosyncratic risk is above both the base level and the level six month before restatement. This trend is seen in Figure 5b. Table 7 Panel $\mathrm{C}$ shows that total risk increases at restatement announcement and remains elevated one year after restatement announcement for firms initiated by the SEC.

Firms whose restatement is initiated by the Auditor have lower beta one year leading up to the restatement (Figure 5). At the same time, idiosyncratic risk for these firms is above those whose restatements are initiated by the SEC and similar to those whose restatements are initiated by the company. Total risk appears similar in this period for firms initiated by the SEC, auditor and the firm. Restatements initiated by the auditor see an increase in all risk measures: beta increases $54 \%$ (from day -1 to day +2 ), idiosyncratic risk increases $55 \%$ (from day -1 to day +4 ), and total risk increases $54 \%$ (from day -1 to day +4 ). As shown in Table 7 this increase in announcement period risk is 
statistically significant. We find that this increase in risk persists for one month following restatement announcement but that all measures of risk return to base levels after that (coefficient b4 is insignificant for Auditor regressions in all panels in Table 7 and is not different than b1). We see a pronounced downward trend in idiosyncratic risk for auditor initiated restatements following restatement announcement.

Lastly, we analyze the changes in measures of risk for restatements originated by the company. We find that the beta for these companies is higher than the beta of companies whose restatement were originated by the auditor, but lower than the beta of the companies whose restatements were originated by the SEC. Those firms experienced the largest increase in beta at restatement announcement: the beta increased $79 \%$ from day -1 to day 3 relative to restatement announcement. The increase in idiosyncratic risk was more modest in this period, it was equal to $33 \%$.

Just like SEC and auditor initiated restatements, company initiated restatements see increase in beta only at announcement and one month after restatement. Beta returns to base level after that (as suggested by significant coefficients b2 and b3, and insignificant coefficient b4 in Table 7 Panel A). Idiosyncratic risk increases 6 months before restatement (b1 is positive and significant in Table 7 Panel B), which is not true for SEC and Auditor initiated restatements. We find that all levels of risk for company initiated restatements returned to base level one month after restatement announcement (coefficient b4 is not significant in Table 7 Panels A. B and C).

Overall, we find that SEC initiated restatements appear to have higher beta but lower idiosyncratic risk leading up to restatements, and continue to have higher beta following the restatement. All types of restatements (SEC, Auditor and Company) 
experience only temporary increase in all measures of risk, with company initiated restatements having the largest increase in beta. For all types risk measures return to prerestatement level one month after restatement.

\subsubsection{Frequency of Restatements}

In this section we examine whether risk measures differ for companies that restate more than once. A failure to solve accounting problems as evidenced by multiple restatements is likely to increase the riskiness of the firm. Kravet and Shevlin (2010) find that the number of times a firm restates affecting the change in the pricing of discretionary information risk. Hence, we expect that the companies that restated more than once would experience bigger changes in the measures of risk.

In our sample, only 5 companies restated their financial statements more than once (one company restated 3 times, 4 restated 2 times). Figure 6 shows that companies that restate more than once have more volatile betas (this could be a result of a smaller sample size). For these firms all measures of risk increase at restatement announcement and both beta and idiosyncratic risk remain elevated one year after the restatement. This results are consistent with the prediction that multiple offenders have poor quality financial statements and therefore have higher risk (Kravet and Shevlin (2010)). We do not perform regression analysis for subsamples of restatements that restated multiple times versus one time offenders because of the small sample size for multiple restatements. 


\subsection{Cross-sectional analysis of changes in risk at restatement announcement}

To test whether the difference between changes in risk around restatement announcement are statistically significant for different sub-samples discussed in section 5.2, we perform cross-sectional analysis (see Table 8). The dependent variable is the mean of the risk measure for the specified period divided by the mean of the respective risk measure during the base period. We analyze cross-sectional determinants in changes in measures of risk during the same periods analyzed in Table $3:(-120 ;-1),(0 ;+5),(+6$; $+26),(+27 ;+250)$. Numbers in parenthesis show days relative to restatement announcement. We include the following variables in the regression: Irregularity, Core and $\log$ (Market Cap). Irregularity is a dummy that equals one if the company announced fraud or an irregularity as a reason for restatement, or if the restating firm was subject to AAER as a result of a restatement. Core is a dummy equal to one if a restatement involved revenue, cost of sales or operating expense accounts for on-going operations, and equals zero otherwise. Market cap is the market capitalization measured at the year end prior to restatement.

In results not tabulated, we regress change in all measures of risk six months before restatement announcement (window $(-120 ;-1)$ ) on explanatory variables. None of these regressions are statistically significant, suggesting that risk six months before restatement is of similar magnitude for all sub-samples. Panel A, Table 8 shows the regression of changes in announcement period returns (window $(0 ;+5)$ ) relative to the base period. The coefficient on $\log$ (Market Cap) is positive and significant in regression for all measures of risk. Coefficient on irregularity dummy is positive and significant in regressions on idiosyncratic and total risk but is insignificant in beta regression. This 
suggests that at restatement announcement beta increases by similar amount for irregularity and no-irregularity, while idiosyncratic risk increases more for irregularity sub-sample. The results are not affected if we estimate announcement period returns over a shorter window: $(0 ;+2) .{ }^{17}$ Panel $\mathrm{B}$ shows the analysis of changes in risk one month after restatement relative to the base period. We find that beta increases more for irregularity and core sub-samples, while idiosyncratic risk and total risk increase more for irregularity sub-sample and larger firms. Panel $\mathrm{C}$ reports the analysis of changes in risk during window $(+27 ;+250)$ relative to the base period. For beta we find that the coefficients on Core and Irregularity dummies are positive and significant. For idiosyncratic risk, the coefficient on Core becomes insignificant (p value equals 0.1056). In Panel $\mathrm{C}$ the coefficient on $\log ($ Market Cap) is insignificant in all regressions. In results not shows we include dummies SEC, Auditor and Company in all models and find the coefficients on these variables to be insignificant.

Overall, cross-sectional analysis reveals that beta increases more for large firms at the restatement announcement, but not in the year following a restatement. In the year following a restatement, beta increases more for irregularity and core restatements. Idiosyncratic risk increases more for the irregularity sub-sample at restatement announcement and after restatement. Large firms experience greater increase in idiosyncratic risk at the restatement announcement and one month after restatement, but not in the window $(+27 ;+250)$.

\subsection{Short-term return and idiosyncratic risk at restatement announcement}

In this section we examine if idiosyncratic risk is priced. To do that we regress announcement period abnormal returns on announcement period idiosyncratic risk. As

\footnotetext{
${ }^{17}$ For all measures of risk and all sub-samples day +2 corresponds to the maximum value of risk measures.
} 
shown in Table 9, the coefficient on idiosyncratic risk is negative and statistically significant at $1 \%$, suggesting an inverse relationship between announcement period abnormal returns and idiosyncratic risk. This negative association is consistent with the volatility feedback hypothesis, whereby higher volatility (in this case idiosyncratic volatility) leads to higher required rates of returns and therefore to lower stock prices (e.g. Campbell and Hentschel 1992).

We also include a number of control variables in this regression. Irregularity is a dummy that equals one if the company announced fraud or an irregularity as a reason for restatement or if restating firm was subject to AAER as a result of a restatement. Core is a dummy that equals one if a restatement involved revenue, cost of sales or operating expense accounts for on-going operations, and equals zero otherwise. Change in NI is the difference between restated Net Income and originally reported Net Income divided by total assets reported in the year preceding restatement announcement. If more than one period is restated, Net Income for all restated periods is added up. NI crosses loss threshold equals one if a restatement changes reported income into a loss and equals zero otherwise. No details is a dummy that equals one if the restatement announcement did not contain all the detail of the restatement. Number of years restated is the number of restated annual reports. SEC, Company and Auditor are dummy variables that equal one if the restatement is initiated by the SEC, company and auditor, respectively. Leverage is the value of long-term debt divided by total assets, calculated at the year end prior to the restatement announcement. Market cap and is measured at the year end prior to the restatement announcement. 
We find that coefficient on Irregularity is negative and statistically significant consistent with our prior findings. We also find that restatements that do not provide all the details about the restatement have a more negative announcement period abnormal return. Surprisingly, we find that the more periods the company restates, the higher its announcement period abnormal return.

\section{Conclusion}

Our study extends prior literature by analyzing the dynamics of equity risk and its idiosyncratic and systematic components of firms that restate financials. We contribute to the literature by modeling the dynamic properties of both systematic and idiosyncratic risk and by reexamining the association between poor quality financial information and the cost of equity using different research design. We define poor quality financial information as material mistakes in annual financial statements which require restatement of previously reported financial statements. Undoubtedly, if a firm has material mistakes in its financial reports, the quality of its financial disclosure is poor. We examine changes in systematic and idiosyncratic risk measures around restatements using a bivariate Exponential GARCH model with time-varying betas, variances and covariances.

We find that idiosyncratic risk increases as early as six months prior to restatement announcement, spikes at the restatement announcement, decreases relative to announcement level and remains at elevated levels relative to pre-restatement period for approximately one year following restatement. The increase in beta is temporary - it experiences a significant increase at restatement announcement but returns to prerestatement level one month following restatement. All measures of risk increase more at 
restatement announcement or following a restatement for restatements involving irregularity or core accounts and for larger firms. Changes in risk differ for restatements originated by SEC, auditor and company as well as for multiple restatements. Overall, our results show that there is significant temporary increase in both risk components with idiosyncratic risk remaining higher over longer periods. Interestingly, we find that there is a negative and significant relation between announcement period return and idiosyncratic risk. The practical implication is that there is a reduction in stock prices, presumably due to a higher required rate of return. The persistence of idiosyncratic volatility following restatements has important implications for the pricing of derivative securities. Rising and persistent volatility will tend to raise the prices of call and put options written on the stocks in question. 


\section{References}

Badertscher B, Burks J (2011) Accounting restatements and the timeliness of disclosures, Accounting Horizons 25 (4): 609-629

Banker RD, Byzalov D, Fang S, Jin B (2019) Operating asymmetries and non-linear spline correction in discretionary accrual models. Review of Quantitative Finance and Accounting, forthcoming.

Bardos K, Golec J, Harding J (2011) Do investors see through mistakes in reported earnings? Journal of Financial and Quantitative Analysis 46 (6): 1917-1946

Bardos K, (2011) Quality of financial information and liquidity. Review of Financial Economics 20: 49-62

Berndt E, Hall H, Hall R, Hausman J (1974) Estimation and inference in nonlinear structural models. Annals of Economic and Social Measurement 4: 653-666

Bollerslev T, Engle R, Nelson D (1994) ARCH models. In: Engle. R.F., McFadden. D.L. (Eds.). Handbook of Econometrics. vol. 4. Elsevier, Amsterdam: 2959-3038

Bollerslev T, Wooldridge J (1992) Quasi-maximum likelihood estimation and inference in dynamic models with time varying- covariances. Econometric Reviews 11: 143-172

Botosan C (1997) Disclosure level and the cost of equity capital. The Accounting Review 72: 323-349

Botosan C (2006) Disclosure and cost of equity capital: What do we know? Accounting and Business Research: International Accounting Policy Forum 36: 31-40

Botosan C, Plumlee M (2002) Re-examination of disclosure level and the expected cost of equity capital. Journal of Accounting Research 40: 21-40

Campbell JY, Hentschel L (1992) No news is good news: An asymmetric model of changing volatility in stock returns. Journal of Financial Economics 31: 281-318

Christensen PO, De La Rosa LE, Feltham GA (2010) Information and the cost of capital: an ex-ante perspective. The Accounting Review 85 (3): 817-848

Cohen DA (2008) Does information risk really matter? An analysis of the determinants and economic consequences of financial reporting quality. Asia-Pacific Journal of Accounting and Economics 15 (2): 69-90

Core JE, Guay WR, Verdi RS (2008) Is accruals quality a priced risk factor? Journal of Accounting and Economics 46: 2-22 
Dechow P, Dichev I (2002) The quality of accruals and earnings: the role of accrual estimation errors. The Accounting Review 77 (Supplement): 35-59

Dechow P M, Ge W, Schrand CM (2010) Understanding earnings quality: a review of the proxies, their determinants and their consequences. Journal of Accounting and Economics 50 (2-3): 344-401

Easley D, O'Hara M (2004) Information and the cost of capital. The Journal of Finance 59 (4): 1553-1583

Easton P, Sommers G (2007) Effects of analysts' optimism on estimates of the expected rate of return implied by earnings forecasts. Journal of Accounting Research 45: 9831015

Ecker F, Francis J, Kim I, Olsson P, Schipper K (2006) A returns-based representation of earnings quality. The Accounting Review 81: 749-780

Elliott JA, Hanna JD, (1996) Repeated accounting write-offs and the information content of earnings. Journal of Accounting Research 34: 135-155

Foster N (2003) The FASB and the capital markets. The FASB Report. Norwalk, CT: FASB.

Francis J, LaFond R, Olsson P, Schipper K (2004) Cost of capital and earnings attributes. The Accounting Review 79: 967-1010

Francis J, LaFond R, Olsson P, Schipper K (2005) The market pricing of accruals quality. Journal of Accounting and Economics 39 (2): 295-327

Francis J, Nanda D, Olsson P (2008) Voluntary disclosure, earnings quality, and the cost of capital. Journal of Accounting Research 46 (1): 53-99

Frankel R, Li X (2004) Characteristics of a firm's information environment and the information asymmetry between insiders and outsiders. Journal of Accounting and Economics 37 (2): 229-259

General Accounting Office (2002) Financial statement restatements: trends, market impacts, regulatory responses, and remaining challenges, GAO-03-138

Gong S, Firth M, Cullinane K (2006) Beta estimation and stability in the US-listed international transportation industry. Review of Pacific Basin Financial Markets and Policies 9(3): 463-490

Goyal A, Santa-Clara P (2003) Idiosyncratic risk matters! The Journal of Finance 58: 975-1008 
Graham J, Li S, Qiu J (2008) Corporate misreporting and bank loan contracting. Journal of Financial Economics 89: 44-61

Han J, Wild J (1990) Unexpected earnings and intra-industry information transfer: further evidence. Journal of Accounting Research 28: 211-219

Hail L (2003) The impact of voluntary corporate disclosures on the ex ante cost of capital for Swiss firms. European Accounting Review 11: 741-743

Healy P, Palepu K (2001) Information asymmetry, corporate disclosure, and the capital markets: a review of the empirical disclosure literature. Journal of Accounting and Economics 31: 405-440

Hennes K, Miller B, Leone A (2008) The importance of distinguishing between errors and irregularities in restatement research: the case of restatements and CEO and CFO turnover. The Accounting Review 83 (6): 1487-1519

Huang HW, Dao M, Sun WC (2017) The timeliness of financial reporting and fair values: evidence from U.S. banks. Review of Pacific Basin Financial Markets and Policies, 20 (1)

Hughes JS, Liu J, Liu J (2007) Information asymmetry, diversification, and cost of capital. The Accounting Review 82 (3): 705-729

Hughes JS, Liu J, Liu J (2009) On the relation between expected returns and implied cost of capital. Review of Accounting Studies 14 (2-3): 246-259

Hribar P, Jenkins N (2004) The effect of accounting restatements on earnings revisions and the estimated cost of capital. Review of Accounting Studies 9: 337-356

Indjejikian R (2007) Discussion of accounting information, disclosure, and the cost of capital. Journal of Accounting Research 45 (2): 421-426

Karpoff JM, Koester A, Lee DS, Martin GS (2017) Proxies and databases in financial misconduct research. The Accounting Review 92 (6): 129-163

Kormendi R, Lipe R (1987) Earnings innovations, earnings persistence, and stock returns. Journal of Business 60: 323-345

Koutmos G, Booth G (1995) Asymmetric volatility transmission in international stock markets. Journal of International Money and Finance 14 (6): 747-762

Kravet T, Shevlin T (2010) Accounting restatements and information risk. Review of Accounting Studies 15 (2): 264-294 
Lambert RA, Leuz C, Verrecchia RE (2007) Accounting information, disclosure, and the cost of capital. Journal of Accounting Research 45 (2): 385-420

Leone A, Rock S, Willenborg M (2007) Disclosure of intended use of proceeds and underpricing in initial public offerings. Journal of Accounting Research 45: 111-115

Leuz C, Wysocki PD (2015) Economic consequences of financial reporting and disclosure regulation: a review and suggestions for future research. Available at SSRN: http://ssrn.com/abstract=1105398.

Levitt A (1998) The importance of high quality accounting standards. Accounting Horizons 12: 79-82

Merton R (1987) A simple model of capital market equilibrium with incomplete information. Journal of Finance 42: 483-510

Nelson DB (1991) Conditional heteroscedasticity in asset returns: a new approach. Econometrica 59: 347-370

Ogneva M (2007) Accrual quality and expected returns: the importance of controlling for cash flow shocks. USC Working Paper

Palmrose ZV, Richardson VJ and Scholz S (2004) Determinants of market reactions to restatement announcements. Journal of Accounting and Economics 37: 59-90

Petersen MA (2009) Estimating standard errors in finance panel data sets: comparing approaches. Review of Financial Studies 22 (1): 435-480

Ramnath S (2002) Investor and analyst reactions to earnings announcements of related firms: An empirical analysis. Journal of Accounting Research 40: 1351-1376

Richardson V, (2000) Information asymmetry and earnings management: some evidence. Review of Quantitative Finance and Accounting: 15 (4), 325-347

Richardson V, Waegelein JF (2002) The influence of long-term performance plans on earnings management and firm performance." Review of Quantitative Finance and Accounting, 18 (2), 161-183

Sakaki H, Jackson D, Jory S (2017) Institutional ownership stability and real earnings management. Review of Quantitative Finance and Accounting, 49 (1), 227-244

Schrand C, Verrecchia R (2005) Information disclosure and adverse selection explanations for IPO underpricing. Wharton School Working Paper

Strong JS, Meyer JR (1987) Asset writedowns: managerial incentives, and securities returns. The Journal of Finance 43: 643-661 
Tuo L, Yu J, Zhang Y (2019) How do industry peers influence individual firms' voluntary disclosure strategies? Review of Quantitative Finance and Accounting. Forthcoming

Verdi R (2006) Information environment and the cost of equity Capital. MIT Sloan School of Management Working Paper

Verrecchia R (2001) Essays on disclosure. Journal of Accounting \& Economics 32: 97 180

Xu, Y, Mlkiel B (2003). Investigating the behavior of idiosyncratic volatility. Journal of Business 76: 613-644

Ye C, Yu LH (2018) The effect of restatements on trading volume reactions to earnings announcements. Review of Quantitative Finance and Accounting 50(1): 129-180

Yen G, Lee CF (2008) Efficient market hypothesis (EMH): past, present and future Review of Pacific Basin Financial Markets and Policies. 11 (2): 305-329

Yu HY, Chen LW (2017) Ambiguous customer identity disclosure and the cost of equity capital. Review of Pacific Basin Financial Markets and Policies 20 (3) 


\section{Figure 1: Changes in risk around restatement announcement - full sample}

This figure presents the changes in firm's mean beta, idiosyncratic risk, and total risk around announcement of financial statement restatements. Horizontal axis shows trading days relative to restatement announcement, with restatement announcement corresponding to day $=0$. All measures of risk are estimated using bivariate Exponential GARCH model with time-varying betas, variances and covariances. Arrow with label "Restatement" points to the observation corresponding to the day of restatement announcement.
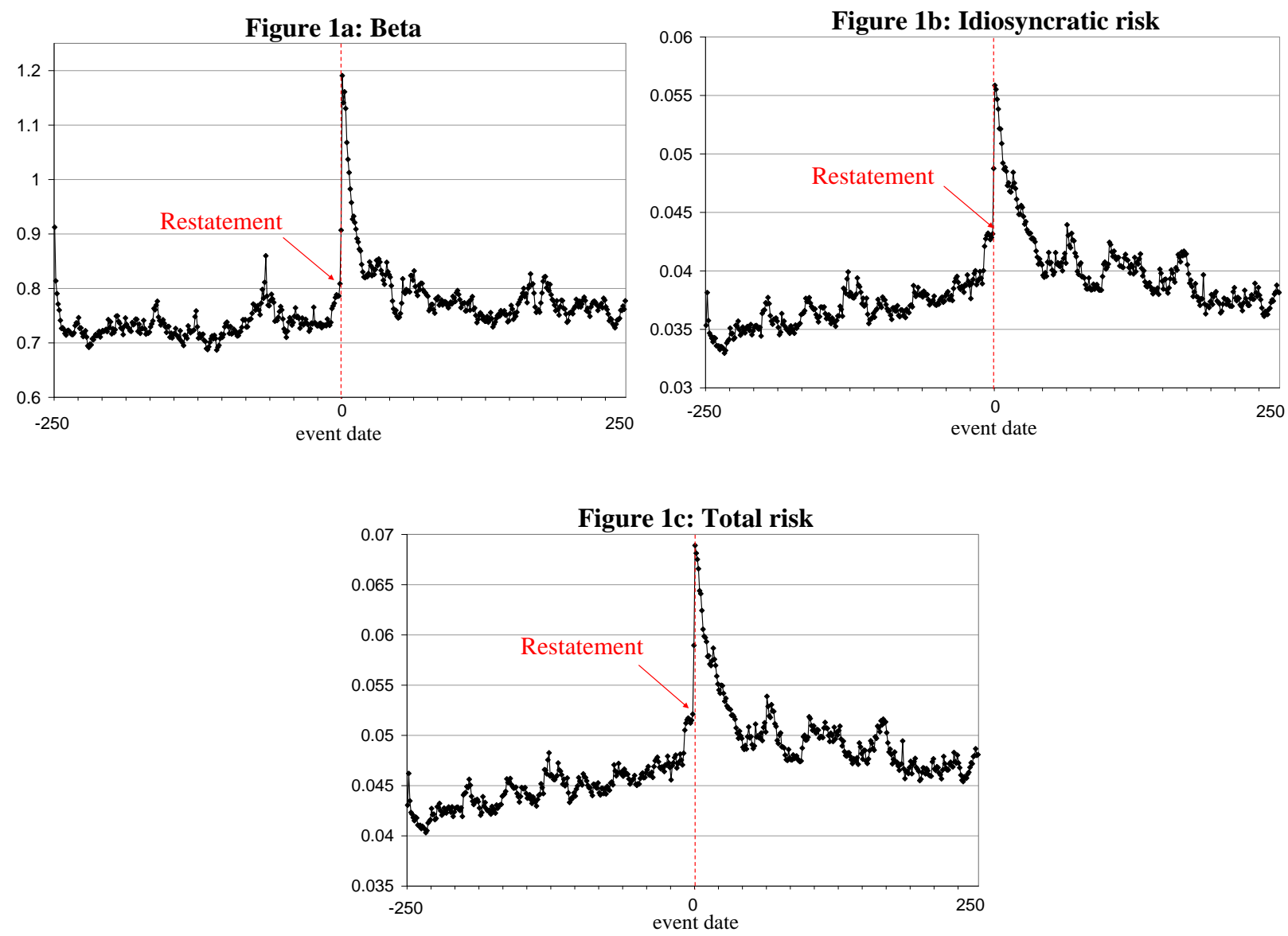


\section{Figure 2: Changes in risk around restatement announcement - irregularity versus no irregularity}

This figure presents the changes in firm's beta, idiosyncratic risk, and total risk around announcement of financial statement restatements for sub-sample with and without irregularity. Horizontal axis shows trading days relative to restatement announcement, with restatement announcement corresponding to day $=0$. Irregularity restatements are those subject to SEC enforcement actions (AAER) or those that disclose an accounting irregularity or fraud as the reason for restatement. All measures of risk are estimated using bivariate Exponential GARCH model with time-varying betas, variances and covariances. Arrow with label "Restatement" points to the observation corresponding to the day of restatement announcement.
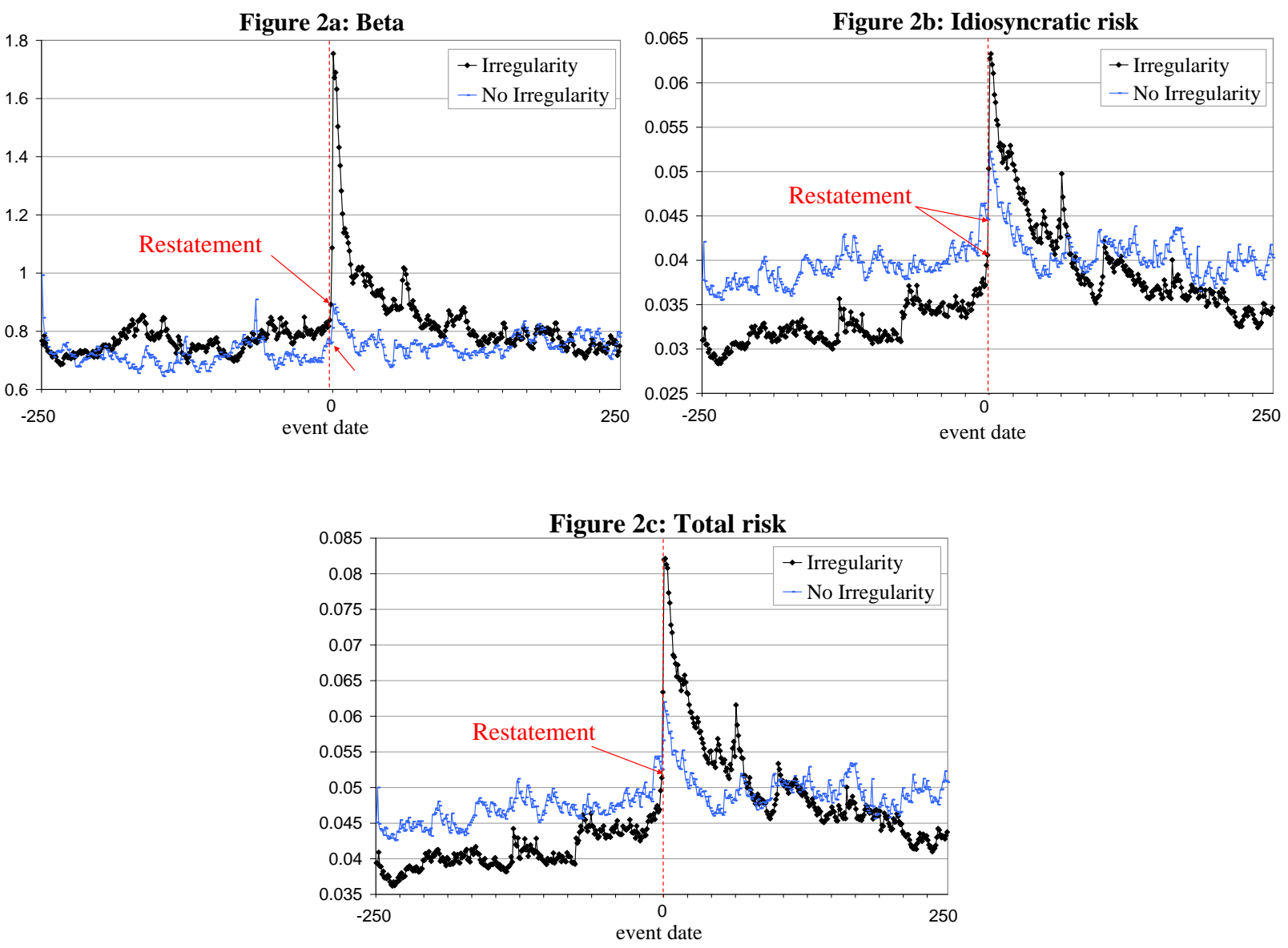
Figure 3: Changes in risk around restatement announcement - core versus non-core This figure presents the changes in firm's beta, idiosyncratic risk, and total risk around announcement of financial statement restatements for core and non-core restatement sub-samples. Horizontal axis shows trading days relative to restatement announcement, with restatement announcement corresponding to day $=0$. Core restatements are defined as those that involve revenue, cost of sales or operating expense accounts for on-going operations. All measures of risk are estimated using bivariate Exponential GARCH model with time-varying betas, variances and covariances. Arrow with label "Restatement" points to the observation corresponding to the day of restatement announcement.
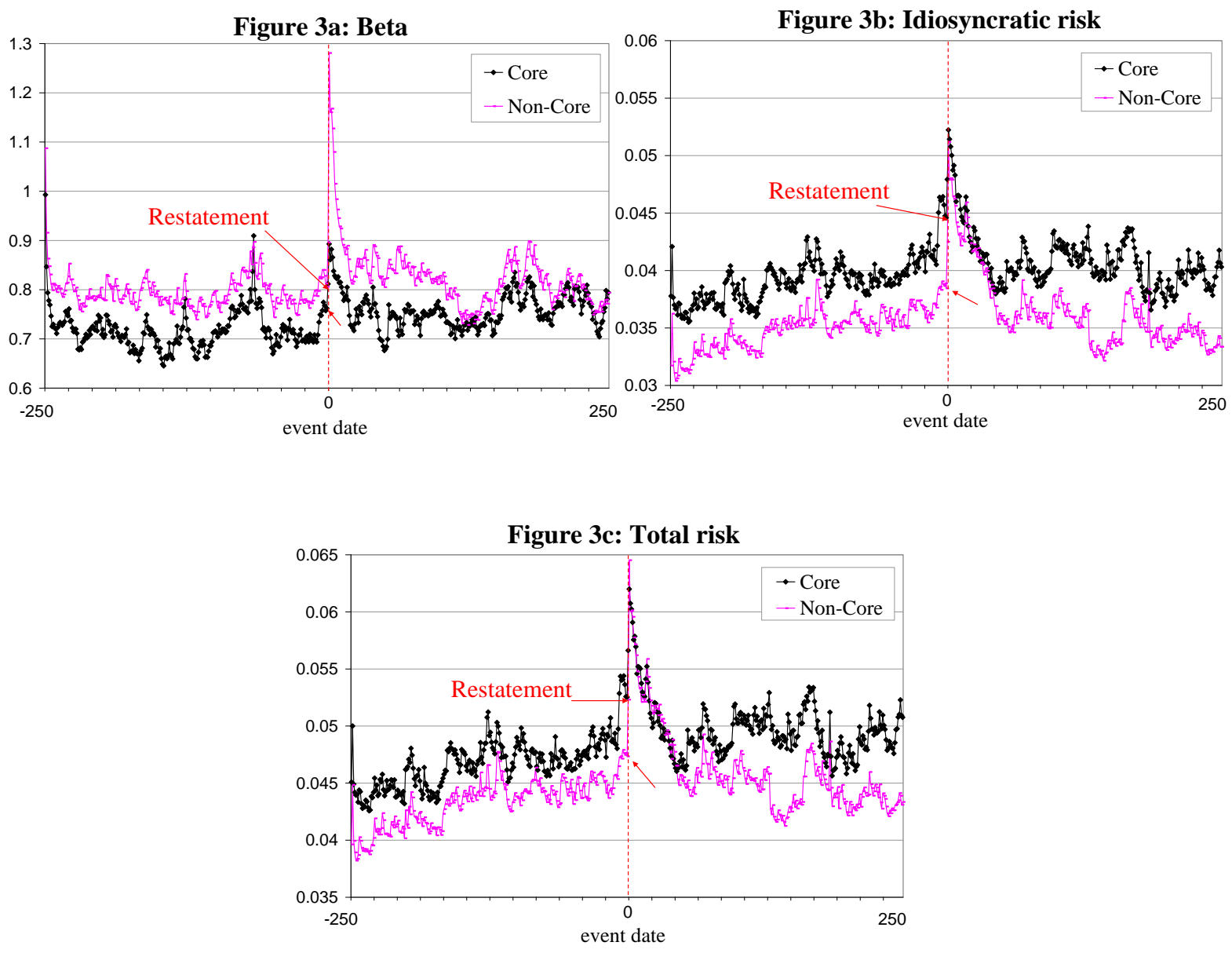


\section{Figure 4: Changes in risk around restatement announcement - large versus small firms}

This figure presents the changes in firm's beta, idiosyncratic risk, and total risk around announcement of financial statement restatements for large and small firms. Horizontal axis shows trading days relative to restatement announcement, with restatement announcement corresponding to day=0. Large (small) firms are defined as above (below) mean logarithm of market capitalization measured at fiscal year end before restatement announcement. All measures of risk are estimated using bivariate Exponential GARCH model with time-varying betas, variances and covariances. Arrow with label "Restatement" points to the observation corresponding to the day of restatement announcement.

Figure 4a: Beta

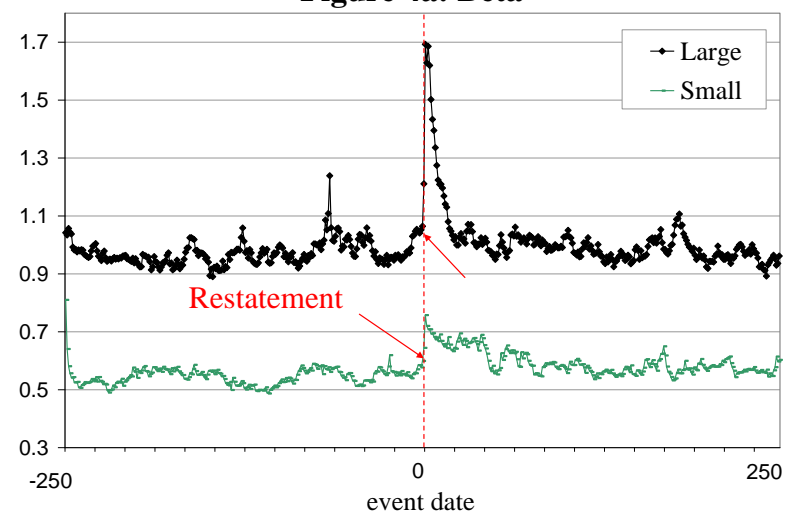

Figure 4b: Idiosyncratic risk

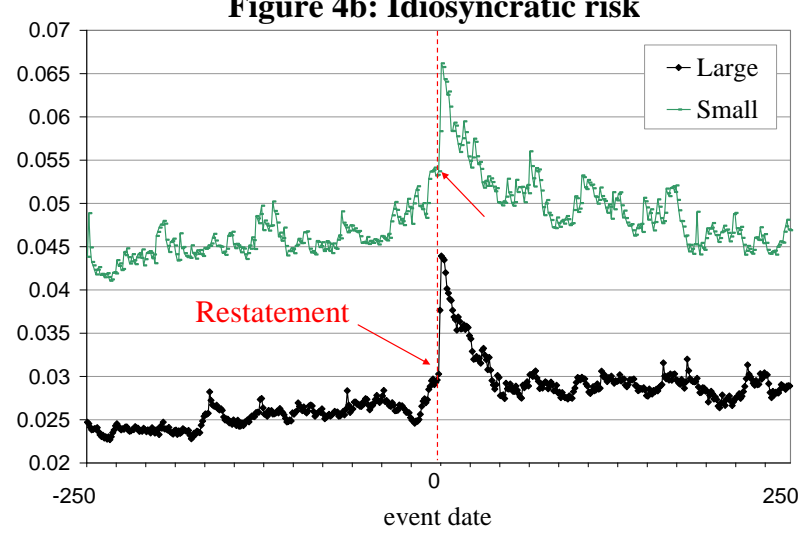

Figure 4c: Total risk

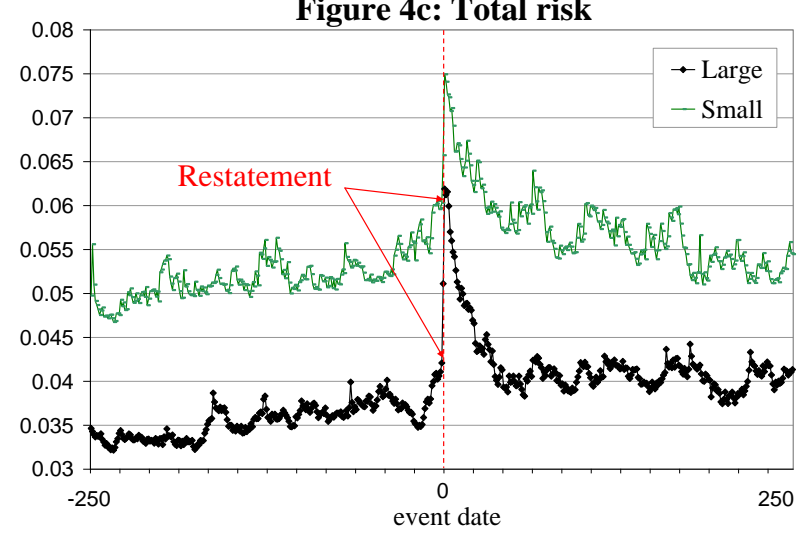




\section{Figure 5: Changes in risk around restatement announcement - restatement initiated by SEC, Auditor and Company}

This figure presents the changes in firm's beta, idiosyncratic risk, and total risk around announcement of financial statement restatements for restatement initiated by SEC, Auditor and Company. Horizontal axis shows trading days relative to restatement announcement, with restatement announcement corresponding to day=0. SEC, Company and Auditor are dummy variables that equal one if the restatement is initiated by the SEC, company and auditor, respectively. All measures of risk are estimated using bivariate Exponential GARCH model with time-varying betas, variances and covariances. Arrow with label "Restatement" points to the observation corresponding to the day of restatement announcement.

Figure 5a: Beta

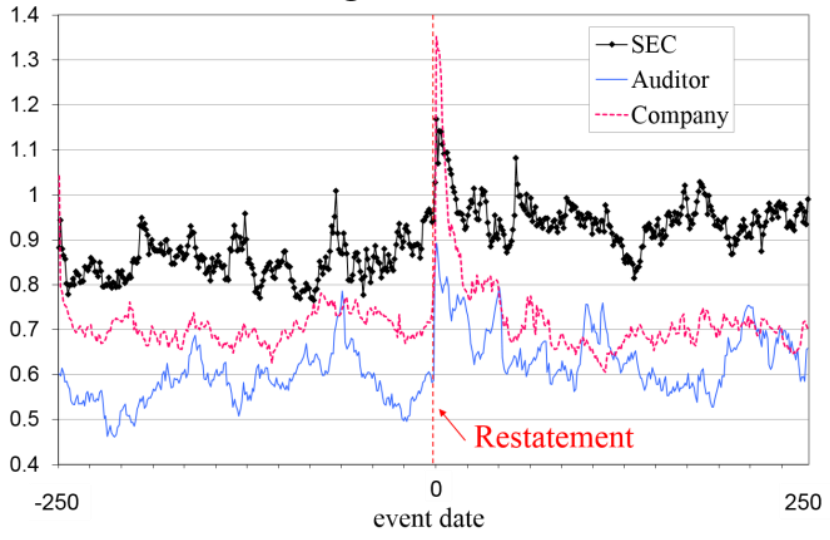

Figure 5b: Idiosyncratic risk

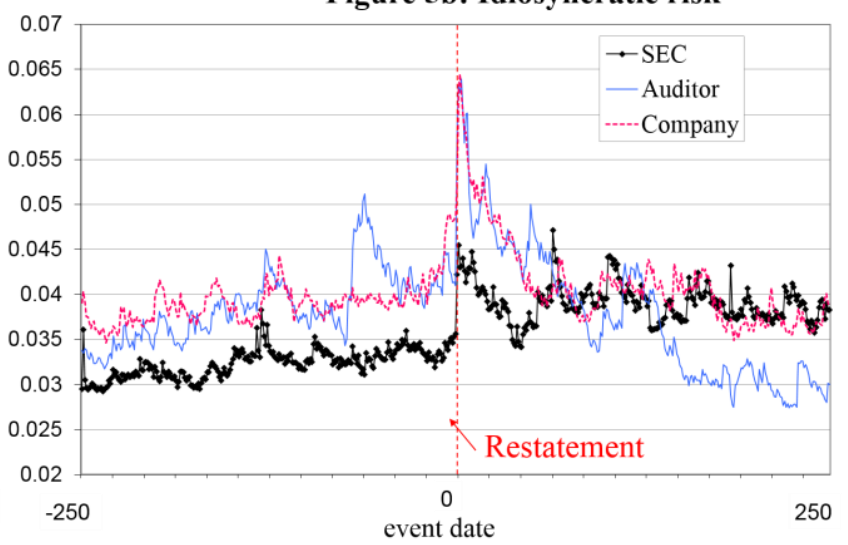

Figure 5c: Total risk

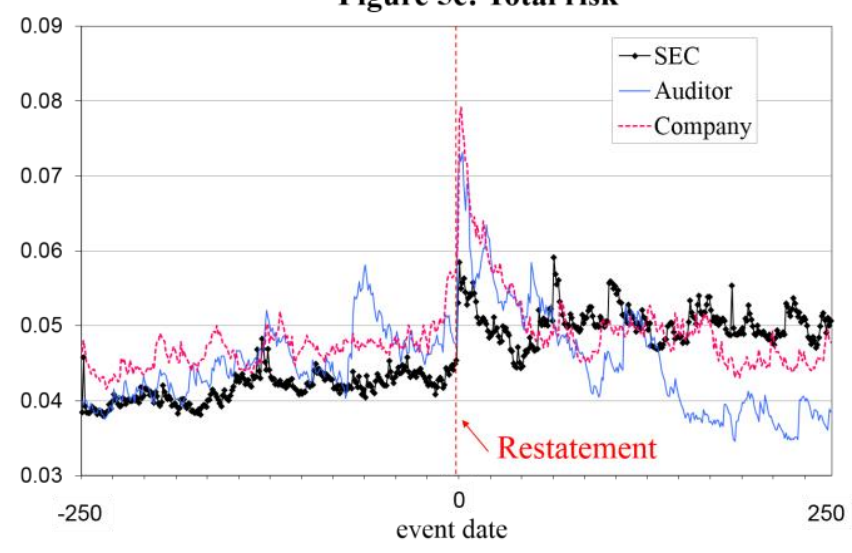




\section{Figure 6: Changes in risk around restatement announcement - restatement frequency}

This figure presents the changes in firm's beta, idiosyncratic risk, and total risk around announcement of financial statement restatements based on the frequency of the restatement. Four companies restated financial statements twice. One company restated financial statement three times. Horizontal axis shows trading days relative to restatement announcement, with restatement announcement corresponding to day $=0$. All measures of risk are estimated using bivariate Exponential GARCH model with time-varying betas, variances and covariances. Arrow with label "Restatement" points to the observation corresponding to the day of restatement announcement.

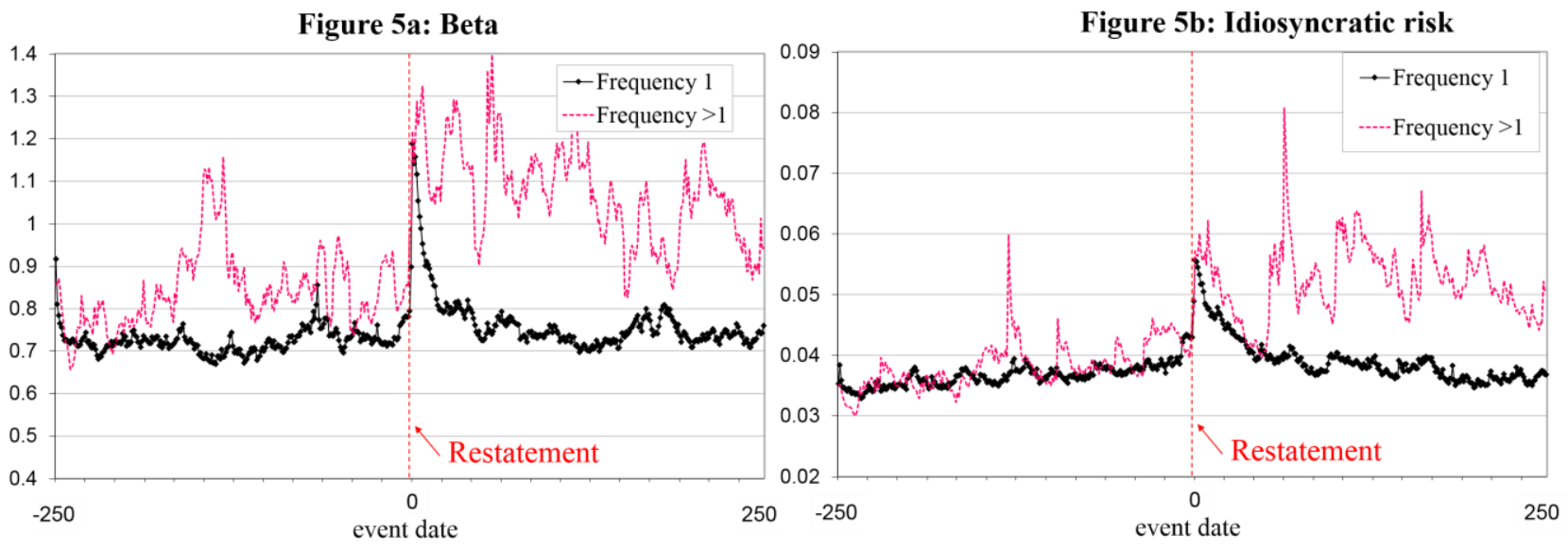

Figure 5c: Total risk

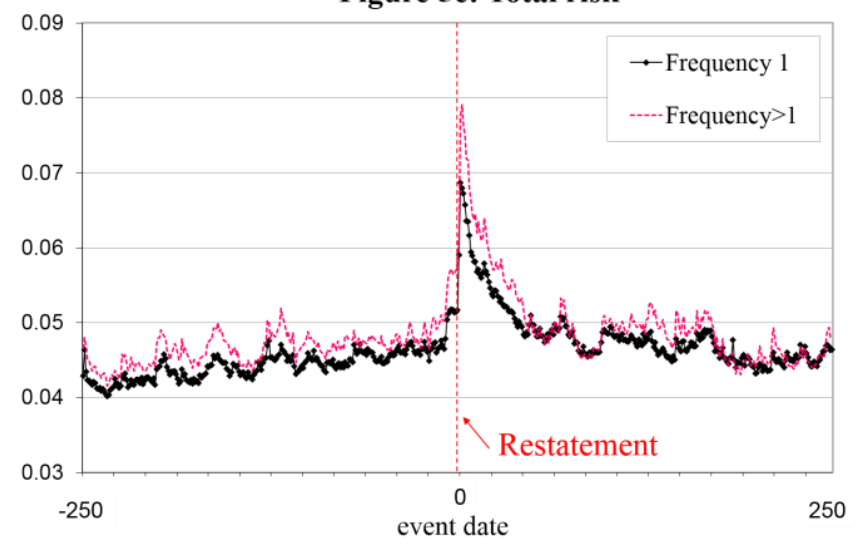




\section{Table 1: Descriptive statistics}

This table shows descriptive statistics for a sample of 143 income decreasing restatements of at least one annual report announced between January 1997 and June 2002. Variables in Panels B and C are hand collected from Lexis-Nexis, Edgar, and Securities and Exchange Commission website. Market cap and total assets are measured at the year end prior to the restatement announcement. Leverage is the value of long-term debt divided by total assets, calculated at the year end prior to the restatement announcement. Number of years restated is the number of restated annual reports. CAR announcement is a market model cumulative abnormal return for days zero and plus one relative to a restatement announcement. Change in NI is the difference between restated Net Income and originally reported Net Income divided by total assets reported in the year preceding restatement announcement. If more than one period is restated, Net Income for all restated periods is added up. NI crosses loss threshold equals one if a restatement changes reported income into a loss and equals zero otherwise. Irregularity is a dummy that equals one if the company announced fraud or an irregularity as a reason for restatement or if restating firm was subject to AAER as a result of a restatement. Core is a dummy that equals one if a restatement involved revenue, cost of sales or operating expense accounts for on-going operations, and equals zero otherwise. No details is a dummy that equals one if the restatement announcement did not contain all the detail of the restatement. SEC, Company and Auditor are dummy variables that equal one if the restatement is initiated by the SEC, company and auditor, respectively.

Panel A: Firm characteristics

\begin{tabular}{|c|c|c|c|c|c|c|}
\hline Variable & Mean & $\begin{array}{c}\text { Lower } \\
\text { Quartile }\end{array}$ & Median & $\begin{array}{c}\text { Upper } \\
\text { Quartile }\end{array}$ & Std & $\mathrm{N}$ \\
\hline Market cap (in millions) & $3,314.5$ & 53.2 & 248.4 & $1,622.2$ & $10,364.0$ & 143 \\
\hline Log (Market cap) & 5.75 & 3.97 & 5.52 & 7.39 & 2.26 & 143 \\
\hline Total assets (in millions) & $4,188.7$ & 93.9 & 428.9 & $2,063.3$ & $12,823.4$ & 143 \\
\hline Leverage & 0.204 & 0.023 & 0.185 & 0.317 & 0.187 & 143 \\
\hline
\end{tabular}

Panel B: Restatement characteristics - continuous variables

\begin{tabular}{|c|c|c|c|c|c|c|}
\hline Variable & Mean & $\begin{array}{c}\text { Lower } \\
\text { Quartile }\end{array}$ & Median & $\begin{array}{c}\text { Upper } \\
\text { Quartile }\end{array}$ & Std & $\mathrm{N}$ \\
\hline Number of years restated & 2.29 & 1.75 & 2.00 & 3.00 & 0.91 & 143 \\
\hline CAR announcement & -0.09 & -0.16 & -0.04 & 0.01 & 0.17 & 139 \\
\hline Change in NI & -0.43 & -0.06 & -0.02 & 0.00 & 4.38 & 140 \\
\hline
\end{tabular}

Panel C: Restatement characteristics - binary variables

\begin{tabular}{lcccc}
\hline Variable & Yes & as a $\%$ & No & as a \% \\
\hline NI crosses loss threshold & 7 & $4.90 \%$ & 136 & $95.10 \%$ \\
Irregularity & 51 & $35.70 \%$ & 92 & $64.30 \%$ \\
Core & 62 & $43.40 \%$ & 81 & $56.60 \%$ \\
No details & 82 & $57.34 \%$ & 61 & $42.66 \%$ \\
SEC & 45 & $31.47 \%$ & 98 & $68.53 \%$ \\
Company & 70 & $48.95 \%$ & 73 & $51.05 \%$ \\
Auditor & 16 & $11.19 \%$ & 127 & $88.81 \%$ \\
\hline
\end{tabular}




\section{Table 2: Univariate analysis of changes in risk around restatement announcement}

This table shows changes in beta, idiosyncratic risk, and total risk around announcement of financial statement restatements. Numbers in parenthesis show trading days relative to restatement announcement, with restatement announcement corresponding to day $=0$. All measures of risk are estimated using bivariate Exponential GARCH model with time-varying betas, variances and covariances.

Panel A: Beta

\begin{tabular}{|c|c|c|c|c|c|}
\hline & \multirow[b]{2}{*}{ Mean } & \multirow{2}{*}{$\begin{array}{c}\% \text { change } \\
\text { relative to base }\end{array}$} & & \multirow{2}{*}{$\begin{array}{c}\% \text { change relative } \\
\text { to base }\end{array}$} & \multirow[b]{2}{*}{$\mathrm{N}$} \\
\hline & & & Median & & \\
\hline Before restatement: $(-250 ;-121)-$ base & 0.7272 & & 0.6382 & & 143 \\
\hline Before restatement: $(-120 ;-1)$ & 0.7397 & $1.7 \%$ & 0.6184 & $-3.1 \%$ & 143 \\
\hline Restatement announcement: $(0 ;+5)$ & 1.0410 & $43.1 \%$ & 0.8278 & $29.7 \%$ & 140 \\
\hline After restatement: $(+6 ;+26)$ & 0.8977 & $23.4 \%$ & 0.7198 & $12.8 \%$ & 136 \\
\hline After restatement: $(+27 ;+250)$ & 0.7845 & $7.9 \%$ & 0.7140 & $11.9 \%$ & 133 \\
\hline
\end{tabular}

Panel B: Idiosyncratic risk

\begin{tabular}{lccccc}
\hline & & $\begin{array}{c}\text { \% change } \\
\text { relative to base }\end{array}$ & Median & $\begin{array}{c}\text { \% change relative } \\
\text { to base }\end{array}$ & $\mathrm{N}$ \\
\hline Before restatement: $(-250 ;-121)$ - base & 0.0356 & & 0.0339 & & 143 \\
Before restatement: $(-120 ;-1)$ & 0.0380 & $6.7 \%$ & 0.0350 & $3.3 \%$ & 143 \\
Restatement announcement: $(0 ;+5)$ & 0.0521 & $46.4 \%$ & 0.0388 & $14.6 \%$ & 140 \\
After restatement: $(+6 ;+26)$ & 0.0486 & $36.5 \%$ & 0.0383 & $13.0 \%$ & 136 \\
After restatement: $(+27 ;+250)$ & 0.0432 & $21.3 \%$ & 0.0363 & $7.3 \%$ & 133 \\
\hline
\end{tabular}

Panel C: Total risk

\begin{tabular}{lccccc}
\hline & & $\begin{array}{c}\% \text { change } \\
\text { relative to base }\end{array}$ & Median & $\begin{array}{c}\text { change relative } \\
\text { to base }\end{array}$ & $\mathrm{N}$ \\
\hline Before restatement: $(-250 ;-121)$ - base & 0.0433 & & 0.0397 & & 143 \\
Before restatement: $(-120 ;-1)$ & 0.0462 & $6.7 \%$ & 0.0447 & $12.6 \%$ & 143 \\
Restatement announcement: $(0 ;+5)$ & 0.0636 & $47.1 \%$ & 0.0495 & $24.8 \%$ & 140 \\
After restatement: $(+6 ;+26)$ & 0.0590 & $36.5 \%$ & 0.0483 & $21.8 \%$ & 136 \\
After restatement: $(+27 ;+250)$ & 0.0525 & $21.3 \%$ & 0.0472 & $19.0 \%$ & 133 \\
\hline
\end{tabular}


Table 3: Regression analysis of changes in risk around restatement announcement This table shows OLS regression of measures of risk on time dummies, with standard errors clusters by restatement. Numbers in parenthesis show trading days relative to restatement announcement, with restatement announcement corresponding to day $=0$. All measures of risk are estimated using bivariate Exponential GARCH model with time-varying betas, variances and covariances. *, **, and *** indicate significance at $10 \%, 5 \%$ and $1 \%$ respectively.

\begin{tabular}{|c|c|c|c|c|c|c|c|}
\hline \multirow{2}{*}{ Dependent variable } & & \multicolumn{2}{|c|}{ Beta } & \multicolumn{2}{|c|}{ Idiosyncratic risk } & \multicolumn{2}{|c|}{ Total risk } \\
\hline & & Coeff. & T-stat & Coeff. & T-stat & Coeff. & T-stat \\
\hline Intercept & & 0.727 & $15.96 * * *$ & 0.036 & $23.64 * * *$ & 0.043 & $27.43 * * *$ \\
\hline Before restatement: $(-120 ;-1)$ & b1 & 0.013 & 0.64 & & & & \\
\hline Before restatement: $(-120 ;-6)$ & b1 & & & 0.002 & $2.95^{* * *}$ & 0.003 & $3.05 * * *$ \\
\hline Before restatement: $(-5 ;-1)$ & b1 & & & 0.007 & $3.01 * * *$ & 0.008 & $3.09 * * *$ \\
\hline Restatement announcement: $(0 ;+5)$ & $\mathrm{b} 2$ & 0.328 & $3.12 * * *$ & 0.016 & $5.69^{* * *}$ & 0.020 & $5.43 * * *$ \\
\hline After restatement: $(+6 ;+26)$ & b3 & 0.173 & $3.51 * * *$ & 0.012 & $4.49 * * *$ & 0.015 & $4.59 * * *$ \\
\hline After restatement: $(+27 ;+250)$ & $\mathrm{b} 4$ & 0.049 & 1.55 & 0.004 & $2.40 * *$ & 0.005 & $3.10 * * *$ \\
\hline \multicolumn{8}{|l|}{ T-test of equivalence of coefficients: } \\
\hline $\mathrm{b} 1=\mathrm{b} 1{ }^{\prime}$ & & & & & $-2.28 * *$ & & $-2.28 * *$ \\
\hline $\mathrm{b} 1=\mathrm{b} 2$ & & & $-3.21 * * *$ & & $-5.29 * * *$ & & $-5.14 * * *$ \\
\hline $\mathrm{b} 1=\mathrm{b} 3$ & & & $-4.06^{* * *}$ & & $-4.06^{* * *}$ & & $-4.25 * * *$ \\
\hline $\mathrm{b} 1=\mathrm{b} 4$ & & & -1.20 & & -1.10 & & $-1.67 *$ \\
\hline $\mathrm{b} 1{ }^{\prime}=\mathrm{b} 2$ & & & & & $-3.92 * * *$ & & $-3.94 * * *$ \\
\hline $\mathrm{b} 1{ }^{\prime}=\mathrm{b} 3$ & & & & & $-1.88 *$ & & $-2.28 * *$ \\
\hline $\mathrm{b} 1{ }^{\prime}=\mathrm{b} 4$ & & & & & 1.52 & & 1.10 \\
\hline $\mathrm{b} 2=\mathrm{b} 3$ & & & $2.09 * *$ & & $2.16^{* *}$ & & $2.42 * *$ \\
\hline $\mathrm{b} 2=\mathrm{b} 4$ & & & $2.68 * * *$ & & $4.72 * * *$ & & $4.25 * * *$ \\
\hline $\mathrm{b} 3=\mathrm{b} 4$ & & & $2.58 * * *$ & & $3.40^{* * *}$ & & $3.16^{* * *}$ \\
\hline $\mathrm{N}$ & & 65,320 & & 65,320 & & 65,320 & \\
\hline Adjusted R-square & & 0.006 & & 0.015 & & 0.018 & \\
\hline F value & & $3.54 * * *$ & & $6.67 * * *$ & & $6.30 * * *$ & \\
\hline
\end{tabular}


Table 4: Regression analysis of changes in risk around restatement announcement irregularity versus no irregularity

This table shows OLS regression of measures of risk on time dummies, with standard errors clusters by restatement. Numbers in parenthesis show trading days relative to restatement announcement, with restatement announcement corresponding to day $=0$. All measures of risk are estimated using bivariate Exponential GARCH model with time-varying betas, variances and covariances. Irregularity restatements are those subject to SEC enforcement actions (AAER) or those that disclose an accounting irregularity or fraud as the reason for restatement. *,*, and $* * *$ indicate significance at $10 \%, 5 \%$ and $1 \%$ respectively.

\section{Panel A: Beta}

Dependent variable Beta

Sub-sample

Coeff

Irregularity

Intercept

0.756

Before restatement: $(-120 ;-1)$

b1

Restatement announcement: $(0 ;+5)$ b2

0.016
Irregularity

After restatement: $(+6 ;+26)$

b3

0.692

9.84***

0.365

0.38

After restatement: $(+27 ;+250)$

b4

0.060

$2.40^{* * *}$

$2.87 * * *$

0.95

No Irregularity

T-test of equivalence of coefficients:

$\mathrm{b} 1=\mathrm{b} 2$

b1 $=b 3$

b1 $=\mathrm{b} 4$

$$
-2.50 * *
$$

$-3.60 * * *$

$-3.72 * * *$

b2 $=$ b3

$-0.72$

$-2.17 * *$

b2 $=\mathrm{b} 4$

1.60

$-0.97$

$\mathrm{b} 3=\mathrm{b} 4$

$2.23 * *$

$2.22 * *$

$2.50 * *$

$2.10^{* *}$

0.93

$\mathrm{N}$

Adjusted R-square

$\mathrm{F}$ value

$3.64 * * *$

$4.64 * * *$ 
Table 4 (continued): Regression analysis of changes in risk around restatement announcement - irregularity versus no irregularity

This table shows OLS regression of measures of risk on time dummies, with standard errors clusters by restatement. Numbers in parenthesis show trading days relative to restatement announcement, with restatement announcement corresponding to day $=0$. All measures of risk are estimated using bivariate Exponential GARCH model with timevarying betas, variances and covariances. Irregularity restatements are those subject to SEC enforcement actions (AAER) or those that disclose an accounting irregularity or fraud as the reason for restatement. *, **, and *** indicate significance at $10 \%, 5 \%$ and $1 \%$ respectively.

Panel B: Idiosyncratic and total risk

\begin{tabular}{|c|c|c|c|c|c|c|c|c|c|}
\hline \multirow{3}{*}{\multicolumn{2}{|c|}{$\begin{array}{l}\text { Dependent variable } \\
\text { Sub-sample } \\
\end{array}$}} & \multicolumn{4}{|c|}{ Idiosyncratic risk } & \multicolumn{4}{|c|}{ Total risk } \\
\hline & & \multirow{2}{*}{\multicolumn{2}{|c|}{$\begin{array}{l}\text { Irregularity } \\
\text { Coeff T-stat } \\
\end{array}$}} & \multicolumn{2}{|c|}{ No Irregularity } & \multicolumn{2}{|c|}{ Irregularity } & \multicolumn{2}{|c|}{ No Irregularity } \\
\hline & & & & Coeff & T-stat & Coeff & T-stat & Coeff & T-stat \\
\hline Intercept & & 0.031 & $15.10 * * *$ & 0.038 & $19.09 * * *$ & 0.039 & $17.10^{* * *}$ & 0.045 & $22.05 * * *$ \\
\hline Before restatement: $(-120 ;-6)$ & b1 & 0.002 & $2.40 * *$ & 0.002 & $2.30 * *$ & 0.003 & $2.33 * *$ & 0.002 & $2.40 * *$ \\
\hline Before restatement: $(-5 ;-1)$ & b1' & 0.007 & $2.22 * *$ & 0.008 & $2.30 * *$ & 0.008 & $2.32 * *$ & 0.008 & $2.31 * *$ \\
\hline Restatement announcement: $(0 ;+5)$ & $\mathrm{b} 2$ & 0.025 & $4.18^{* * *}$ & 0.011 & $4.04 * * *$ & 0.034 & $3.88 * * *$ & 0.013 & $4.25 * * *$ \\
\hline After restatement: $(+6 ;+26)$ & b3 & 0.021 & $3.38^{* * *}$ & 0.007 & $3.26^{* * *}$ & 0.027 & $3.46 * * *$ & 0.008 & $3.52 * * *$ \\
\hline After restatement: $(+27 ;+250)$ & b4 & 0.007 & $2.84 * * *$ & 0.002 & 1.10 & 0.009 & $2.99 * * *$ & 0.004 & $1.73 *$ \\
\hline \multicolumn{10}{|l|}{ T-test of equivalence of coefficients: } \\
\hline $\mathrm{b} 1=\mathrm{b} 1{ }^{\prime}$ & & & $-1.66^{*}$ & & $-1.76^{*}$ & & $-1.72 *$ & & $-1.71^{*}$ \\
\hline $\mathrm{b} 1=\mathrm{b} 2$ & & & $-4.12 * * *$ & & $-3.42 * * *$ & & $-3.84 * * *$ & & $-3.62 * * *$ \\
\hline $\mathrm{b} 1=\mathrm{b} 3$ & & & $-3.27 * * *$ & & $-2.47 * *$ & & $-3.42 * * *$ & & $-2.70 * * *$ \\
\hline $\mathrm{b} 1=\mathrm{b} 4$ & & & $-2.07 * *$ & & -0.07 & & $-2.09 * *$ & & -0.60 \\
\hline $\mathrm{b} 11^{\prime}=\mathrm{b} 2$ & & & $-3.66 * * *$ & & $-1.78^{*}$ & & $-3.44 * * *$ & & $-2.13 * *$ \\
\hline $\mathrm{b} 11^{\prime}=\mathrm{b} 3$ & & & $-3.36 * * *$ & & 0.24 & & $-3.34 * * *$ & & 0.04 \\
\hline $\mathrm{b} 11^{\prime}=\mathrm{b} 4$ & & & -0.16 & & $1.73^{*}$ & & -0.31 & & 1.36 \\
\hline $\mathrm{b} 2=\mathrm{b} 3$ & & & 0.94 & & $2.21 * *$ & & 1.26 & & $2.35 * *$ \\
\hline $\mathrm{b} 2=\mathrm{b} 4$ & & & $3.48^{* * *}$ & & $3.21 * * *$ & & $3.12 * * *$ & & $3.02 * * *$ \\
\hline $\mathrm{b} 3=\mathrm{b} 4$ & & & $2.63 * * *$ & & $2.14 * *$ & & $2.62 * * *$ & & $1.81 *$ \\
\hline $\mathrm{N}$ & & \multicolumn{2}{|c|}{23,479} & \multicolumn{2}{|c|}{41,841} & \multicolumn{2}{|c|}{23,479} & \multicolumn{2}{|r|}{41,841} \\
\hline Adjusted R-square & & \multicolumn{2}{|c|}{0.042} & \multirow{2}{*}{\multicolumn{2}{|c|}{0.006}} & \multicolumn{2}{|c|}{$\begin{array}{c}0.049 \\
3.64 * * *\end{array}$} & \multicolumn{2}{|r|}{0.007} \\
\hline F value & & \multicolumn{2}{|c|}{$3.75 * * *$} & & $4.16^{* * *}$ & \multicolumn{2}{|c|}{$3.64 * * *$} & \multicolumn{2}{|r|}{$4.64 * * *$} \\
\hline
\end{tabular}




\section{Table 5: Regression analysis of changes in risk around restatement announcement - core versus non-core}

This table shows OLS regression of measures of risk on time dummies, with standard errors clusters by restatement. Numbers in parenthesis show trading days relative to restatement announcement, with restatement announcement corresponding to day $=0$. All measures of risk are estimated using bivariate Exponential GARCH model with time-varying betas, variances and covariances. Core restatements are defined as those that involve revenue, cost of sales or operating expense accounts for on-going operations. *, $* *$, and $* * *$ indicate significance at $10 \%, 5 \%$ and $1 \%$ respectively.

\section{Panel A: Beta}

Dependent variable

Sub-sample

Beta

\begin{tabular}{|c|c|c|c|c|c|}
\hline \multirow[t]{2}{*}{ Sub-sample } & & \multicolumn{2}{|c|}{ Core } & \multicolumn{2}{|r|}{ Non-Core } \\
\hline & & Coeff & T-stat & Coeff & T-stat \\
\hline Intercept & & 0.71 & $12.51 * * *$ & 0.79 & $11.77 * * *$ \\
\hline Before restatement: $(-120 ;-1)$ & b1 & 0.01 & 0.53 & 0.00 & 0.03 \\
\hline Restatement announcement: $(0 ;+5)$ & $\mathrm{b} 2$ & 0.13 & $3.45 * * *$ & 0.28 & $1.90 *$ \\
\hline After restatement: $(+6 ;+26)$ & b3 & 0.07 & $2.43 * *$ & 0.10 & $1.93 *$ \\
\hline After restatement: $(+27 ;+250)$ & b4 & 0.04 & 1.23 & 0.02 & 0.47 \\
\hline \multicolumn{6}{|l|}{ T-test of equivalence of coefficients: } \\
\hline $\mathrm{b} 1=\mathrm{b} 2$ & & & $-3.72 * * *$ & & $-1.93 *$ \\
\hline $\mathrm{b} 1=\mathrm{b} 3$ & & & $-2.17 * *$ & & $-2.12 *$ \\
\hline $\mathrm{b} 1=\mathrm{b} 4$ & & & -0.97 & & -0.55 \\
\hline $\mathrm{b} 2=\mathrm{b} 3$ & & & $2.22 * *$ & & 1.50 \\
\hline $\mathrm{b} 2=\mathrm{b} 4$ & & & $2.10 * *$ & & $1.84 *$ \\
\hline $\mathrm{b} 3=\mathrm{b} 4$ & & & 0.93 & & $1.97 * *$ \\
\hline $\mathrm{N}$ & \multicolumn{3}{|c|}{41,841} & & 37,862 \\
\hline Adjusted R-square & \multicolumn{3}{|c|}{0.002} & & 0.003 \\
\hline F value & \multicolumn{3}{|c|}{$3.66 * * *$} & & 1.34 \\
\hline
\end{tabular}




\section{Table 5 (continued): Regression analysis of changes in risk around restatement announcement - core versus non-core}

This table shows OLS regression of measures of risk on time dummies, with standard errors clusters by restatement. Numbers in parenthesis show trading days relative to restatement announcement, with restatement announcement corresponding to day $=0$. All measures of risk are estimated using bivariate Exponential GARCH model with timevarying betas, variances and covariances. Core restatements are defined as those that involve revenue, cost of sales or operating expense accounts for on-going operations. *, **, and *** indicate significance at $10 \%, 5 \%$ and $1 \%$ respectively.

Panel B: Idiosyncratic and total risk

\begin{tabular}{|c|c|c|c|c|c|c|c|c|c|}
\hline \multirow{2}{*}{\multicolumn{2}{|c|}{$\begin{array}{l}\text { Dependent variable } \\
\text { Sub-sample }\end{array}$}} & \multicolumn{4}{|c|}{ Idiosyncratic risk } & \multicolumn{4}{|c|}{ Total risk } \\
\hline & & \multicolumn{2}{|c|}{ Core } & \multicolumn{2}{|c|}{ Non-Core } & \multicolumn{2}{|c|}{ Core } & \multicolumn{2}{|c|}{ Non-Core } \\
\hline & & Coeff & T-stat & Coeff & T-stat & Coeff & T-stat & Coeff & T-stat \\
\hline Intercept & & 0.038 & $19.09 * * *$ & 0.034 & $16.17 * * *$ & 0.045 & $22.05 * * *$ & 0.042 & $18.72 * * *$ \\
\hline Before restatement: $(-120 ;-6)$ & b1 & 0.002 & $2.3 * *$ & 0.002 & $2.75 * * *$ & 0.002 & $2.40^{* *}$ & 0.003 & $2.87 * * *$ \\
\hline Before restatement: $(-5 ;-1)$ & b1' & 0.008 & $2.30 * *$ & 0.005 & $2.09 * *$ & 0.008 & $2.31 * *$ & 0.006 & $2.10^{* *}$ \\
\hline Restatement announcement: $(0 ;+5)$ & b2 & 0.011 & $4.04 * * *$ & 0.012 & $4.09 * * *$ & 0.013 & $4.25 * * *$ & 0.015 & $4.04 * * *$ \\
\hline After restatement: $(+6 ;+26)$ & b3 & 0.007 & $3.26 * * *$ & 0.010 & $2.79 * * *$ & 0.008 & $3.52 * * *$ & 0.012 & $3.06^{* * *}$ \\
\hline After restatement: $(+27 ;+250)$ & b4 & 0.002 & 1.10 & 0.002 & 1.07 & 0.004 & $1.73^{*}$ & 0.003 & 1.56 \\
\hline \multicolumn{10}{|l|}{ T-test of equivalence of coefficients: } \\
\hline $\mathrm{b} 1=\mathrm{b} 1{ }^{\prime}$ & & & $-1.76^{*}$ & & -1.31 & & $-1.71 *$ & & -1.26 \\
\hline $\mathrm{b} 1=\mathrm{b} 2$ & & & $-3.42 * * *$ & & $-3.57 * * *$ & & $-3.62 * * *$ & & $-3.48 * * *$ \\
\hline $\mathrm{b} 1=\mathrm{b} 3$ & & & $-2.47 * *$ & & $-2.25 * *$ & & $-2.70 * * *$ & & $-2.45 * *$ \\
\hline $\mathrm{b} 1=\mathrm{b} 4$ & & & -0.07 & & 0.23 & & -0.60 & & -0.22 \\
\hline $\mathrm{b} 11^{\prime}=\mathrm{b} 2$ & & & $-1.78 *$ & & $-3.24 * * *$ & & $-2.13 * *$ & & $-3.15 * * *$ \\
\hline $\mathrm{b} 11^{\prime}=\mathrm{b} 3$ & & & 0.24 & & $-2.10 * *$ & & 0.04 & & $-2.32 * *$ \\
\hline b1'=b4 & & & $1.73^{*}$ & & 1.43 & & 1.36 & & 1.06 \\
\hline $\mathrm{b} 2=\mathrm{b} 3$ & & & $2.21 * *$ & & 1.01 & & $2.35^{* *}$ & & 1.31 \\
\hline $\mathrm{b} 2=\mathrm{b} 4$ & & & $3.21 * * *$ & & $3.89 * * *$ & & $3.02 * * *$ & & $3.71 * * *$ \\
\hline $\mathrm{b} 3=\mathrm{b} 4$ & & & $2.14 * *$ & & $2.48 * *$ & & $1.81^{*}$ & & $2.55 * * *$ \\
\hline $\mathrm{N}$ & & \multicolumn{2}{|c|}{41,841} & \multicolumn{2}{|c|}{37,862} & \multicolumn{2}{|c|}{41,841} & \multicolumn{2}{|r|}{37,862} \\
\hline Adjusted R-square & & \multicolumn{2}{|c|}{0.006} & \multicolumn{2}{|c|}{0.009} & \multicolumn{2}{|c|}{0.020} & \multicolumn{2}{|r|}{0.002} \\
\hline F value & & \multicolumn{2}{|c|}{$4.16^{* * *}$} & \multicolumn{2}{|c|}{$4.32 * * *$} & \multicolumn{2}{|c|}{$4.90 * * *$} & \multicolumn{2}{|r|}{$3.66 * * *$} \\
\hline
\end{tabular}




\section{Table 6: Regression analysis of changes in risk around restatement announcement - large versus small firms}

This table shows OLS regression of measures of risk on time dummies, with standard errors clusters by restatement. Numbers in parenthesis show trading days relative to restatement announcement, with restatement announcement corresponding to day $=0$. All measures of risk are estimated using bivariate Exponential GARCH model with time-varying betas, variances and covariances. Large (small) firms are defined as above (below) mean logarithm of market capitalization measured at fiscal year end before restatement announcement. *, **, and $* * *$ indicate significance at $10 \%, 5 \%$ and $1 \%$ respectively.

\section{Panel A: Beta}

Dependent variable

Sub-sample

\begin{tabular}{|c|c|c|c|c|c|}
\hline \multirow[t]{2}{*}{ Sub-sample } & & \multicolumn{2}{|c|}{ Large firms } & \multicolumn{2}{|c|}{ Small firms } \\
\hline & & Coeff & T-stat & Coeff & T-stat \\
\hline Intercept & & 0.971 & $12.62 * * *$ & 0.530 & $12.29 * * *$ \\
\hline Before restatement: $(-120 ;-1)$ & $\mathrm{b} 1$ & 0.026 & 0.64 & 0.002 & 0.11 \\
\hline Restatement announcement: $(0 ;+5)$ & b2 & 0.513 & $2.34 * *$ & 0.148 & $3.97 * * *$ \\
\hline After restatement: $(+6 ;+26)$ & b3 & 0.205 & $2.15^{* *}$ & 0.122 & $3.18 * * *$ \\
\hline After restatement: $(+27 ;+250)$ & b4 & 0.030 & 0.51 & 0.037 & 1.25 \\
\hline \multicolumn{6}{|l|}{ T-test of equivalence of coefficients: } \\
\hline $\mathrm{b} 1=\mathrm{b} 2$ & & & $-2.50 * *$ & & $-3.25 * * *$ \\
\hline $\mathrm{b} 1=\mathrm{b} 3$ & & & -0.07 & & -1.25 \\
\hline $\mathrm{b} 1=\mathrm{b} 4$ & & & $1.99 * *$ & & 1.17 \\
\hline $\mathrm{b} 2=\mathrm{b} 3$ & & & $2.24 * *$ & & $3.08 * * *$ \\
\hline $\mathrm{b} 2=\mathrm{b} 4$ & & & $1.89 *$ & & $2.52 * * *$ \\
\hline $\mathrm{b} 3=\mathrm{b} 4$ & & & $-2.39 * *$ & & $-4.19 * * *$ \\
\hline $\mathrm{N}$ & & & 30,225 & & 35,095 \\
\hline Adjusted R-square & & & 0.008 & & 0.005 \\
\hline F value & & & 1.72 & & $4.43 * * *$ \\
\hline
\end{tabular}


Table 6 (continued): Regression analysis of changes in risk around restatement announcement - large versus small firms

Panel B: Idiosyncratic and total risk

\begin{tabular}{|c|c|c|c|c|c|c|c|c|c|}
\hline \multirow{2}{*}{\multicolumn{2}{|c|}{$\begin{array}{l}\text { Dependent variable } \\
\text { Sub-sample }\end{array}$}} & \multicolumn{4}{|c|}{ Idiosyncratic risk } & \multicolumn{4}{|c|}{ Total risk } \\
\hline & & \multirow{2}{*}{\multicolumn{2}{|c|}{$\begin{array}{l}\text { Large firms } \\
\text { Coeff } \mathrm{T} \text {-stat }\end{array}$}} & \multicolumn{2}{|c|}{ Small firms } & \multicolumn{2}{|c|}{ Large firms } & \multicolumn{2}{|c|}{ Small firms } \\
\hline & & & & Coeff & T-stat & Coeff & T-stat & Coeff & T-stat \\
\hline Intercept & & 0.024 & $17.53 * * *$ & 0.045 & $22.91 * * *$ & 0.034 & $18.22^{* * *}$ & 0.051 & $24.31 * * *$ \\
\hline Before restatement: $(-120 ;-6)$ & b1 & 0.002 & $2.67 * * *$ & 0.002 & $2.22 * *$ & 0.003 & $2.70 * * *$ & 0.003 & $2.16 * *$ \\
\hline Before restatement: $(-5 ;-1)$ & b1' & 0.005 & $2.05^{* *}$ & 0.009 & $2.39 * *$ & 0.006 & $2.18 * *$ & 0.010 & $2.36 * *$ \\
\hline Restatement announcement: $(0 ;+5)$ & $\mathrm{b} 2$ & 0.016 & $3.51 * * *$ & 0.018 & $4.86 * * *$ & 0.022 & $3.35^{* * *}$ & 0.020 & $4.91 * * *$ \\
\hline After restatement: $(+6 ;+26)$ & b3 & 0.012 & $2.64 * * *$ & 0.014 & $4.39 * * *$ & 0.015 & $2.75^{* * *}$ & 0.015 & $4.49^{* * *}$ \\
\hline After restatement: $(+27 ;+250)$ & $\mathrm{b} 4$ & 0.005 & $2.73 * * *$ & 0.005 & $1.92 *$ & 0.007 & $2.96 * * *$ & 0.006 & $2.25^{* *}$ \\
\hline \multicolumn{10}{|l|}{ T-test of equivalence of coefficients: } \\
\hline $\mathrm{b} 1=\mathrm{b} 1^{\prime}$ & & & -1.47 & & $-1.83 *$ & & -1.47 & & $-1.81 *$ \\
\hline $\mathrm{b} 1=\mathrm{b} 2$ & & & $-3.37 * * *$ & & $-4.36 * * *$ & & $-3.21 * * *$ & & $-4.45 * * *$ \\
\hline $\mathrm{b} 1=\mathrm{b} 3$ & & & $-2.38 * *$ & & $-3.99 * * *$ & & $-2.51 * * *$ & & $-4.15 * * *$ \\
\hline $\mathrm{b} 1=\mathrm{b} 4$ & & & $-1.95^{*}$ & & -0.86 & & $-1.94 *$ & & -1.19 \\
\hline $\mathrm{b} 11^{\prime}=\mathrm{b} 2$ & & & $-2.91 * * *$ & & $-3.09 * * *$ & & $-2.82 * * *$ & & $-3.24 * * *$ \\
\hline $\mathrm{b} 11^{\prime}=\mathrm{b} 3$ & & & $-2.21 * *$ & & -1.15 & & $-2.22 * *$ & & -1.4 \\
\hline $\mathrm{b} 11^{\prime}=\mathrm{b} 4$ & & & 0.12 & & 1.35 & & -0.09 & & 1.07 \\
\hline $\mathrm{b} 2=\mathrm{b} 3$ & & & 1.27 & & $1.75^{*}$ & & $1.67^{*}$ & & $1.75^{*}$ \\
\hline $\mathrm{b} 2=\mathrm{b} 4$ & & & $2.65 * * *$ & & $4.02 * * *$ & & $2.46 * *$ & & $3.90 * * *$ \\
\hline $\mathrm{b} 3=\mathrm{b} 4$ & & & $1.70^{*}$ & & $3.28 * * *$ & & $1.68^{*}$ & & $3.13 * * *$ \\
\hline $\mathrm{N}$ & & & 30,225 & & 35,095 & & 30,225 & & 35,095 \\
\hline Adjusted R-square & & & 0.026 & & 0.015 & & 0.018 & & 0.013 \\
\hline F value & & & $3.02 * *$ & & $69 * * *$ & & $.10 * * *$ & & $4.40 * * *$ \\
\hline
\end{tabular}




\section{Table 7: Changes in risk around restatement announcement - SEC, Auditor and Company}

This table shows OLS regression of measures of risk on time dummies, with standard errors clusters by restatement. Numbers in parenthesis show trading days relative to restatement announcement, with restatement announcement corresponding to day $=0$. All measures of risk are estimated using bivariate Exponential GARCH model with time-varying betas, variances and covariances. SEC, Company and Auditor are dummy variables that equal one if the restatement is initiated by the SEC, company and auditor, respectively.*, **, and $* * *$ indicate significance at $10 \%, 5 \%$ and $1 \%$ respectively.

Panel A: Beta

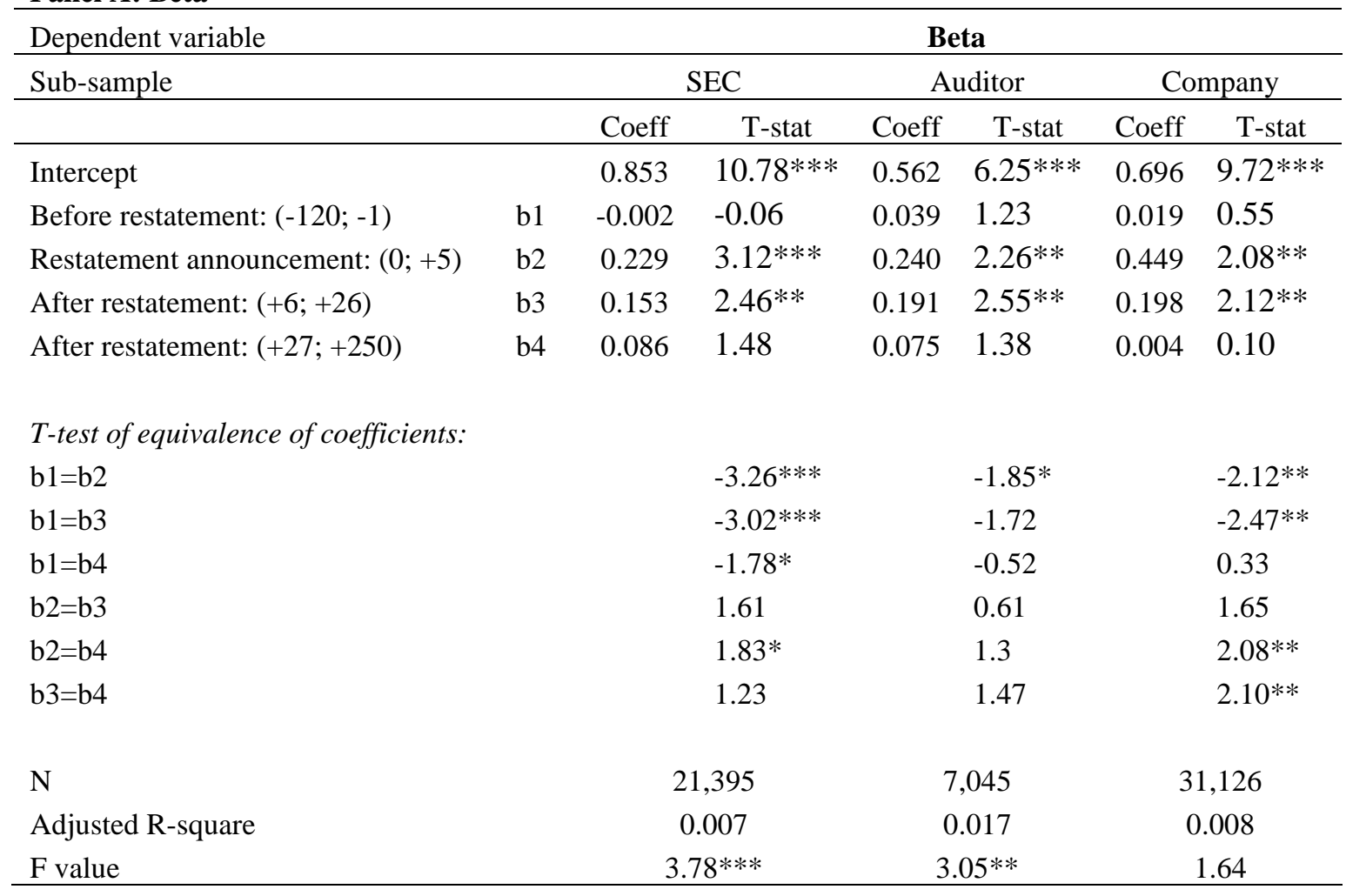


Table 7 (continued): Changes in risk around restatement announcement - SEC, Auditor and Company

Panel B: Idiosyncratic risk

\begin{tabular}{|c|c|c|c|c|c|c|c|}
\hline \multirow{3}{*}{$\begin{array}{l}\text { Dependent variable } \\
\text { Sub-sample }\end{array}$} & & \multicolumn{6}{|c|}{ Idiosyncratic risk } \\
\hline & & \multicolumn{2}{|c|}{ SEC } & \multicolumn{2}{|c|}{ Auditor } & \multicolumn{2}{|c|}{ Company } \\
\hline & & Coeff & T-stat & Coeff & T-stat & Coeff & T-stat \\
\hline Intercept & & 0.032 & $13.66 * * *$ & 0.037 & $6.43 * * *$ & 0.038 & $17.17 * * *$ \\
\hline Before restatement: $(-120 ;-1)$ & b1 & 0.002 & 1.63 & 0.004 & 1.59 & 0.002 & $1.97 * *$ \\
\hline Restatement announcement: $(0 ;+5)$ & $\mathrm{b} 2$ & 0.011 & $3.30 * * *$ & 0.022 & $3.09 * * *$ & 0.020 & $3.93 * * *$ \\
\hline After restatement: $(+6 ;+26)$ & b3 & 0.009 & $3.02 * * *$ & 0.015 & $3.02 * * *$ & 0.014 & $2.72 * * *$ \\
\hline After restatement: $(+27 ;+250)$ & $\mathrm{b} 4$ & 0.007 & $3.08^{* * *}$ & 0.000 & -0.13 & 0.002 & 0.72 \\
\hline \multicolumn{8}{|l|}{ T-test of equivalence of coefficients: } \\
\hline $\mathrm{b} 1=\mathrm{b} 2$ & & & $-3.04 * * *$ & & $-2.75 * *$ & & $-3.79 * * *$ \\
\hline $\mathrm{b} 1=\mathrm{b} 3$ & & & $-2.82 * * *$ & & $-2.24 * *$ & & $-2.52 * *$ \\
\hline $\mathrm{b} 1=\mathrm{b} 4$ & & & $-2.27 * *$ & & 1.10 & & 0.15 \\
\hline $\mathrm{b} 2=\mathrm{b} 3$ & & & 0.52 & & 1.51 & & $1.85^{*}$ \\
\hline $\mathrm{b} 2=\mathrm{b} 4$ & & & 0.95 & & $2.86^{* *}$ & & $4.24 * * *$ \\
\hline \multirow[t]{2}{*}{$\mathrm{b} 3=\mathrm{b} 4$} & & & 0.63 & & $3.58 * * *$ & & $2.79 * * *$ \\
\hline & & & 1,395 & & & & \\
\hline $\mathrm{N}$ & & & & \multicolumn{2}{|c|}{7,045} & \multicolumn{2}{|r|}{31,126} \\
\hline Adjusted R-square & & & .025 & \multicolumn{2}{|c|}{0.019} & \multicolumn{2}{|r|}{0.015} \\
\hline F value & & \multicolumn{2}{|c|}{$4.34 * * *$} & \multicolumn{2}{|c|}{$3.23 * *$} & \multicolumn{2}{|c|}{$4.46^{* * *}$} \\
\hline
\end{tabular}


Table 7 (continued): Changes in risk around restatement announcement - SEC, Auditor and Company

Panel C: Total risk

Dependent variable

\begin{tabular}{lccccccc}
\hline Sub-sample & \multicolumn{3}{c}{ SEC } & \multicolumn{2}{c}{ Auditor } & \multicolumn{2}{c}{ Company } \\
\hline & & Coeff & T-stat & Coeff & T-stat & Coeff & T-stat \\
\hline Intercept & & 0.041 & $16.13^{* * *}$ & 0.043 & $7.58^{* * *}$ & 0.046 & $19.18^{* * *}$ \\
Before restatement: $(-120 ;-1)$ & b1 & 0.002 & 1.60 & 0.005 & 1.59 & 0.003 & $2.07^{* *}$ \\
Restatement announcement: $(0 ;+5)$ & b2 & 0.013 & $3.50^{* * *}$ & 0.024 & $3.07 * * *$ & 0.026 & $3.70^{* * *}$ \\
After restatement: $(+6 ;+26)$ & b3 & 0.011 & $3.22^{* * *}$ & 0.017 & $3.21^{* * *}$ & 0.017 & $2.82^{* * *}$ \\
After restatement: $(+27 ;+250)$ & b4 & 0.009 & $3.34^{* * *}$ & 0.001 & 0.33 & 0.003 & 1.08
\end{tabular}

T-test of equivalence of coefficients:

$\mathrm{b} 1=\mathrm{b} 2$

$\mathrm{b} 1=\mathrm{b} 3$

$\mathrm{b} 1=\mathrm{b} 4$

$\mathrm{b} 2=\mathrm{b} 3$

$\mathrm{b} 2=\mathrm{b} 4$

b3 $=b 4$

$-3.18 * * *$

$-2.73^{* *}$

$-3.62 * * *$

$-2.92 * * *$

$-2.46^{* *}$

$-2.68 * * *$

-2.50 **

0.77

$-0 . .06$

0.82

1.34

$2.05 * *$

0.95

$2.67 * *$

$3.66^{* * *}$

0.43

$3.49 * * *$

$2.64 * * *$

$\mathrm{N}$

21,395

Adjusted R-square

0.032

7,045

31,126

$F$ value

$4.71 * * *$

0.020

0.019

$3.20 * *$

$3.56 * * *$ 


\section{Table 8: Cross-sectional analysis of changes in risk measures at restatement announcement}

This table shows cross-sectional analysis of changes in risk measures for various windows relative to the base period. Base period measures of risk are calculated for window $(-250 ;-121)$. Numbers in parenthesis show trading days relative to restatement announcement, with restatement announcement corresponding to day $=0$. All measures of risk are estimated using bivariate Exponential GARCH model with time-varying betas, variances and covariances as average announcement measures divided by average base period measures. Irregularity is a dummy that equals one if the company announced fraud or an irregularity as a reason for restatement or if restating firm was subject to AAER as a result of a restatement. Core is a dummy that equals one if a restatement involved revenue, cost of sales or operating expense accounts for on-going operations, and equals zero otherwise. Market cap is the market capitalization measured at the year end prior to restatement. *,**, and *** indicate significance at $10 \%, 5 \%$ and $1 \%$ respectively.

Panel A: Announcement period risk measures (window $(0 ;+5)$ )

\begin{tabular}{lcccccc}
\hline Dependent variable & \multicolumn{2}{c}{ Beta } & \multicolumn{2}{c}{ Idiosyncratic risk } & \multicolumn{2}{c}{ Total risk } \\
\hline Intercept & Coeff & T-stat & Coeff & T-stat & Coeff & T-stat \\
Irregularity & 0.717 & $2.49^{* *}$ & 0.454 & 1.23 & 0.566 & $1.68^{*}$ \\
Core & 0.296 & 1.48 & 0.522 & $2.05^{* *}$ & 0.485 & $2.08^{* *}$ \\
Log (Market cap) & 0.225 & 1.18 & 0.373 & 1.53 & 0.340 & 1.52 \\
& 0.094 & $2.14^{* *}$ & 0.136 & $2.43^{* *}$ & 0.117 & $2.28^{* *}$ \\
$\mathrm{~N}$ & \multicolumn{2}{c}{140} & \multicolumn{2}{c}{140} & & \multicolumn{2}{c}{140} \\
Adjusted R-square & \multicolumn{2}{c}{0.048} & \multicolumn{2}{c}{0.081} & \multicolumn{2}{c}{0.077} \\
F value & \multicolumn{2}{c}{$3.34^{* *}$} & \multicolumn{2}{c}{$5.09^{* * *}$} & \multicolumn{2}{c}{$4.85^{* * *}$} \\
\hline
\end{tabular}

Panel B: Post-restatement risk measures (window $(+6 ;+26)$ )

\begin{tabular}{lcccccc}
\hline Dependent variable & \multicolumn{2}{c}{ Beta } & \multicolumn{2}{c}{ Idiosyncratic risk } & \multicolumn{2}{c}{ Total risk } \\
& Coeff & T-stat & Coeff & T-stat & Coeff & T-stat \\
\hline Intercept & 0.980 & $5.32^{* * *}$ & 0.513 & 1.56 & 0.628 & $2.15^{* *}$ \\
Irregularity & 0.222 & $1.71^{*}$ & 0.518 & $2.23^{* *}$ & 0.483 & $2.35^{* *}$ \\
Core & 0.213 & $1.75^{*}$ & 0.303 & 1.39 & 0.282 & 1.46 \\
Log (Market cap) & 0.028 & 0.98 & 0.110 & $2.18^{* *}$ & 0.089 & $1.99^{* *}$ \\
& & & & & & \\
$\mathrm{~N}$ & \multicolumn{2}{c}{136} & \multicolumn{2}{c}{136} & \multicolumn{2}{c}{136} \\
Adjusted R-square & \multicolumn{2}{c}{0.035} & \multicolumn{2}{c}{0.082} & \multicolumn{2}{c}{0.810} \\
F value & \multicolumn{2}{c}{$2.63^{* *}$} & \multicolumn{2}{c}{$52^{* * *}$} & $4.96^{* * *}$ \\
\hline
\end{tabular}

Panel C: Post-restatement risk measures (window $(+27 ;+250)$ )

\begin{tabular}{lcccccc}
\hline Dependent variable & \multicolumn{2}{c}{ Beta } & \multicolumn{2}{c}{ Idiosyncratic risk } & \multicolumn{2}{c}{ Total risk } \\
& Coeff & T-stat & Coeff & T-stat & Coeff & T-stat \\
\hline Intercept & 0.940 & $6.07^{* * *}$ & 0.906 & $4.47^{* * *}$ & 0.946 & $5.06^{* * *}$ \\
Irregularity & 0.185 & $1.74^{*}$ & 0.306 & $2.20^{* *}$ & 0.279 & $2.18^{* *}$ \\
Core & 0.214 & $2.12^{* *}$ & 0.216 & 1.63 & 0.213 & $1.75^{*}$ \\
Log (Market cap) & 0.010 & 0.44 & 0.034 & 1.09 & 0.026 & 0.93 \\
& & & & & & \\
N & \multicolumn{2}{c}{133} & \multicolumn{2}{c}{133} & & 133 \\
Adjusted R-square & \multicolumn{2}{c}{0.038} & \multicolumn{2}{c}{0.050} & \multicolumn{2}{c}{0.049} \\
F value & \multicolumn{2}{c}{$2.74^{* *}$} & $3.33^{* *}$ & $3.25^{* *}$ \\
\hline
\end{tabular}




\section{Table 9: Short-term abnormal returns and idiosyncratic risk at restatement announcement}

This table shows the results of the regression of CAR announcement for a sample of 136 income decreasing restatements of at least one annual report announced between January 1997 and June 2002. CAR announcement is a market model cumulative abnormal return for days zero and plus one relative to a restatement announcement. Idiosyncratic risk is as measured by EGARCH model at restatement announcement. Irregularity is a dummy that equals one if the company announced fraud or an irregularity as a reason for restatement or if restating firm was subject to AAER as a result of a restatement. Core is a dummy that equals one if a restatement involved revenue, cost of sales or operating expense accounts for on-going operations, and equals zero otherwise. Change in NI is the difference between restated Net Income and originally reported Net Income divided by total assets reported in the year preceding restatement announcement. If more than one period is restated, Net Income for all restated periods is added up. NI crosses loss threshold equals one if a restatement changes reported income into a loss and equals zero otherwise. No details is a dummy that equals one if the restatement announcement did not contain all the detail of the restatement. Number of years restated is the number of restated annual reports. SEC, Company and Auditor are dummy variables that equal one if the restatement is initiated by the SEC, company and auditor, respectively. Leverage is the value of long-term debt divided by total assets, calculated at the year end prior to the restatement announcement. Market cap and is measured at the year end prior to the restatement announcement.

\begin{tabular}{lrl}
\hline & Coeff & T stat \\
\hline Intercept & -0.011 & -0.17 \\
Idiosyncratic risk & -0.030 & $-3.18^{* * *}$ \\
Irregularity & -0.081 & $-2.70^{* * *}$ \\
Core & -0.018 & -0.66 \\
Change in NI & 0.001 & 0.28 \\
NI crosses loss threshold & -0.047 & -0.65 \\
No details & -0.082 & $-3.05^{* * *}$ \\
Number of years restated & 0.036 & $2.34^{* *}$ \\
SEC & -0.045 & -0.87 \\
Company & -0.008 & -0.17 \\
Auditor & 0.002 & 0.03 \\
Leverage & -0.021 & -0.29 \\
Log (Market cap) & 0.001 & 0.13 \\
& & \\
N & 136 & \\
Adjusted R-square & 0.1543 & \\
F value & $3.05^{* * *}$ & \\
\hline
\end{tabular}

